\author{
Jarosław Prońko, D.Sc., JKU prof.a)*; sen. brig. Jacek Zboina, Ph.D. ${ }^{\text {b); }}$ \\ sen. brig. (retd.) Jan Kielin, M.Sc. Eng. ${ }^{\text {b); }}$ Beata Wojtasiak, M.A. ${ }^{\text {b); }}$ Marta Iwańska, M.A. ${ }^{\text {b) }}$ \\ a) Jan Kochanowski University in Kielce, the Institute of Management / Uniwersytet Jana Kochanowskiego w Kielcach, \\ Instytut Zarządzania \\ b) Scientific and Research Centre for Fire Protection - National Research Institute / Centrum Naukowo-Badawcze Ochrony \\ Przeciwpożarowej im. Józefa Tuliszkowskiego - Państwowy Instytut Badawczy \\ Corresponding author / Autor korespondencyjny: jaroslaw.pronko@ujk.edu.pl
}

\title{
Statistical Modelling of Emergency Service Responses
}

\section{Modelowanie statystyczne reakcji służb ratowniczych}

\begin{abstract}
Aim: The aim of this article is to demonstrate the applicability of historical emergency-response data - gathered from decision-support systems of emergency services - in emergency-response statistical modelling.

Project and methods: Building models of real phenomena is the first step in making and rationalising decisions regarding these phenomena. The statistical modelling presented in this article applies to critical-event response times for emergency services - counted from the moment the event is reported to the beginning of the rescue action by relevant services. And then, until the action is completed and services are ready for a new rescue action. The ability to estimate these time periods is essential for the rational deployment of rescue services taking into account the spatial density of (possible) critical events and the critical assessment of the readiness of these services. It also allows the assessment of the availability of emergency services, understood as the number of emergency teams which ensure operational effectiveness in the designated area.

The article presents the idea of modelling emergency response times, the methods to approximate the distribution of random variables describing the individual stages and practical applications of such approximations. Due to editorial limitations, the article includes the results only for one district (powiat - second-level unit of local government and administration in Poland).

Results: A number of solutions proposed in the article can be considered innovative, but special attention should be given to the methodology to isolate random variables included in the analysed database as single random variables. This methodology was repeatedly tested with a positive result. The study was based on data on critical events and emergency response times collected in the computerised decision-support system of the State Fire Service (PSP) in Poland.

Conclusions: Presented in this article, the method of approximating the duration of individual stages of emergency response based on theoretical distributions of random variables is largely consistent with the empirical data. It also allows to predict how the system will work in the short-term (over a time span of several years). The predictive property of such modelling can be used to optimise the deployment and to determine the capabilities of individual rescue teams. These studies were conducted between 2012 and 2015 as part of a project funded by the National Centre for Research and Development (NCBR), agreement No. DOBR/0015/R/ID1/2012/03
\end{abstract}

Keywords: statistical modelling, data mining, emergency services, designing rescue systems

Type of article: original scientific article

Received: 11.06.2019; Reviewed: 21.06.2019; Accepted: 28.06.2019;

Authors' ORCID IDs: J. Prońko - 0000-0003-2944-9592; J.Zboina - 0000-0002-9436-5830; B. Wojtasiak - 0000-0001-5741-1079;

J. Kielin - 0000-0002-3506-5424; M. Iwańska - 0000-0003-4815-7296;

The authors contributed equally to this article;

Please cite as: SFT Vol. 53 Issue 1, 2019, pp. 8-31, https://doi.org/10.12845/sft.51.3.2019.1;

This is an open access article under the CC BY-SA 4.0 license (https://creativecommons.org/licenses/by-sa/4.0/).

\section{ABSTRAKT}

Cel: Celem artykułu jest zaprezentowanie możliwości wykorzystania danych historycznych dotyczących reakcji służb ratowniczych, gromadzonych w systemach wspomagania decyzji ich dysponentów, do statystycznego modelowania reakcji tych służb.

Projekt i metody: Budowanie modeli rzeczywistych zjawisk stanowi pierwszy etap podejmowania i racjonalizacji decyzji dotyczących tych zjawisk. Zjawiskiem, którego modelowanie (w ujęciu statystycznym) prezentujemy w niniejszym artykule, jest czas reakcji służb ratowniczych na zaistniałe incydenty krytyczne - liczony od momentu zgłoszenia zdarzenia do podjęcia działań ratowniczych przez odpowiednie służby, a następnie ich zakończenia oraz 
odzyskania gotowości do powtórnej reakcji. Umiejętność oszacowania tych czasów jest niezbędna do racjonalnego rozmieszczenia służb ratowniczych na tle przestrzennej gęstości (możliwych) zdarzeń krytycznych oraz oceny stopnia gotowości tych służb. Pozwala ona również na oszacowanie dostępności służb ratowniczych, rozumianej jako liczba zespołów ratowniczych zapewniających skuteczność działań w wyznaczonym rejonie.

W artykule zaprezentowano ideę modelowania czasu reakcji służb ratowniczych, metody aproksymacji rozkładów zmiennych losowych opisujących poszczególne jej etapy oraz praktyczne jej wykorzystanie. Ze względu na ograniczenia edytorskie zaprezentowano wyniki analiz jedynie dla jednego powiatu. Wyniki: Szereg proponowanych w artykule rozwiązań można zaliczyć do nowatorskich, a na szczególną uwagę zasługuje metodyka rozdzielenia zmiennych losowych ujętych w analizowanej bazie jako jedna zmienna losowa. Metodykę tę przetestowano wielokrotnie z pozytywnym rezultatem.

Badania oparto na danych o zaistniałych incydentach krytycznych oraz czasach reakcji służb ratowniczych gromadzonych w systemie informatycznym wspomagania decyzji dysponentów Państwowej Straży Pożarnej w Polsce.

Wnioski: Wskazany w niniejszym artykule sposób aproksymacji czasu trwania poszczególnych etapów procesu reagowania służb ratowniczych, teoretycznymi rozkładami zmiennych losowych pozwala na przewidywanie działania tego systemu w krótkiej (kilkuletniej) perspektywie czasowej. Własność predykcyjna takiego modelowania może być wykorzystana do optymalizacji rozmieszczenia i określenia potencjału poszczególnych jednostek ratowniczych. Badania te przeprowadzono w ramach projektu finansowanego przez Narodowe Centrum Badań i Rozwoju (nr umowy: D0BR/0015/R/ID1/2012/03 w latach 2012-2015). Typ artykułu: oryginalny artykuł naukowy

Słowa kluczowe: modelowanie statystyczne, eksploracja danych, służby ratownicze, projektowanie systemów ratowniczych

Przyjęty: 11.06.2019; Zrecenzowany: 21.06.2019; Zatwierdzony: 28.06.2019;

Identyfikatory ORCID autorów: J. Prońko - 0000-0003-2944-9592, J.Zboina - 0000-0002-9436-5830; B. Wojtasiak - 0000-0001-5741-1079;

J. Kielin - 0000-0002-3506-5424; M. Iwańska - 0000-0003-4815-7296;

Autorzy wnieśli równy wkład merytoryczny w powstanie artykułu;

Proszę cytować: SFT Vol. 53 Issue 1, 2019, pp. 8-31, https://doi.org/10.12845/sft.51.3.2019.1;

Artykuł udostępniany na licencji CC BY-SA 4.0 (https://creativecommons.org/licenses/by-sa/4.0/).

\section{Introduction}

The main indicator of the effectiveness of emergency services is the time it takes them to reach the site of the incident and to commence effective rescue operations. Studies conducted as part of the project Zaawansowane technologie teleinformatyczne wspomagające projektowanie systemu ratowniczego na poziomach: gmina, powiat, województwo (Advanced information and communication technologies supporting the design of the rescue system on the following levels: commune, district, province' ${ }^{\prime}$ ) indicate that the recommended time of arrival of the emergency services to the scene should be no longer than:

- 12 minutes - traffic accidents;

- 13 minutes - fires;

- 20 minutes - other incidents (see [8]).

The indicated values are associated with the ability to provide effective medical care to the injured. These times can be affected by many factors, including:

- predispositions and training of people being part of the incident information flow system;

- training and readiness of the rescuers;

- technical capabilities of the equipment used by the emergency services;

- transport infrastructure of the area;

- weather conditions;

Project implemented by a consortium of SGSP, CNBOP-PIB, WSZiP, Asseco Poland S.A., ITTI Sp. z o.o. between 2012 and 2015. Funded by NCBR, Agreement No.: DOBR/0015/R/ID1/2012/03.

\section{Wprowadzenie}

Podstawowym wskaźnikiem oceny skuteczności działania służb ratowniczych jest czas, w jakim mogą one dotrzeć na miejsce zdarzenia i podjąć skuteczne działania ratownicze. $Z$ badań prowadzonych w ramach projektu Zaawansowane technologie teleinformatyczne wspomagające projektowanie systemu ratowniczego na poziomach: gmina, powiat, województwo ${ }^{1}$ wynika, że rekomendowany czas dotarcia służb ratowniczych na miejsce zdarzenia powinien być nie większy niż:

- 12 min - wypadki komunikacyjne;

- 13 min - pożary;

- 20 min - inne zdarzenia (zob. [8]).

Wskazane wartości związane są z możliwością udzielenia skutecznej pomocy medycznej osobom poszkodowanym. $\mathrm{Na}$ czas ten wpływa wiele czynników:

- predyspozycje i wyszkolenie osób tworzących system przepływu informacji o zdarzeniu;

- wyszkolenie i gotowość ratowników;

- możliwości techniczne sprzętu, którym dysponują służby ratownicze;

- infrastruktura komunikacyjna terenu;

- warunki pogodowe;

- pora dnia (ze względu na możliwości psychofizyczne ratowników);

Projekt realizowany przez konsorcjum: SGSP, CNBOP-PIB, WSZiP im. H. Chodkowskiej, Asseco Poland S.A., ITTI Sp. z o.o. w latach 2012-2015. Finansowany przez NCBR, nr umowy. DOBR/0015/R/ID1/2012/03. 
- time of day - relevant to the psychophysical capabilities of the rescuers;

- random difficulties in reaching the scene.

Therefore, a question arises: Is it possible to mathematically describe the response time of the emergency services?

Information systems are commonly used to transfer, process and store information. They facilitate the collection of extensive and highly detailed information. Moreover, they can be used for various types of analyses, as well as to support decision-making processes by providing selected data needed by decision-makers.

Data collected in these systems and advanced computer applications allow highly detailed and targeted analyses. These data and applications have been used to describe emergency response times. The studies described in this article were conducted as part of the aforementioned project funded by NCBiR. Data used in these studies was collected in the Decision Support System for Management Positions of PSP (State Fire Brigade), the FireBird SWD-ST 2.5 version.

The aim of this study was to develop a statistical model describing emergency response times and its applicability in:

- estimating the operational responsibility area of individual rescue teams;

- designing an indicator of rescue-team readiness to act;

- assessing the number of rescue teams which ensure operational effectiveness in the designated area - in this case, the critical-event emergence process must be additionally described.

This model can be used for analyses that are based on the following methods:

- classical - mathematical analysis;

- Monte Carlo - time simulation of individual emergencyresponse stages according to the predefined theoretical distributions of random variables;

- methods using neural networks to generate individual times based on historical data.

The reliability of this model is based on two hypotheses we will try to prove, at least partially, in this article:

- empirical distributions of the duration of individual reaction phases can be reasonably approximated using theoretical distributions of random variables;

- parametersandshapesofthedistributionswhichdescribe individual emergency-response phases are constant, at least at intervals of several years.

The article is divided into four main parts:

- the concept underlying the model - describing the main assumptions of the model and method of its application to estimate: the operational responsibility area, the rescue-team readiness indicator and the availability of emergency services;

- data source - describing the basic parameters of the database used during the study;

- modelling split times - describing the methods of approximating empirical distributions (historical data)
- pojawiające się przypadkowo zakłócenia w dotarciu na miejsce zdarzenia.

Pojawia się zatem pytanie, czy czas reakcji służb ratowniczych można w wiarygodny sposób opisać matematycznie?

Do przekazywania, przetwarzania i gromadzenia informacji powszechnie wykorzystuje się systemy informatyczne. Pozwalają one na gromadzenie znacznych ilości bardzo szczegółowych informacji. Można je wykorzystywać do różnego typu analiz, a także do wspomagania procesów decyzyjnych poprzez dostarczanie wyselekcjonowanych danych niezbędnych decydentowi.

Dane zgromadzone we wspomnianych systemach oraz zawansowane aplikacje komputerowe umożliwiają prowadzenie bardzo szczegółowych i ukierunkowanych analiz. Narzędzi tych użyto do opisu czasu reakcji służb ratowniczych. Badania takie przeprowadzono $\mathrm{w}$ ramach projektu finansowanego przez NCBiR. Wykorzystano w nich dane gromadzone w Systemie Wspomagania Decyzji dla Stanowisk Kierowania PSP w wersji FireBird SWD-ST 2,5.

Celem badań było skonstruowanie statystycznego modelu opisującego czas reagowania służb ratowniczych oraz jego zastosowanie do:

- szacowania rejonu odpowiedzialności operacyjnej poszczególnych jednostek ratowniczych;

- konstrukcji wskaźnika gotowości operacyjnej zespołów ratowniczych;

- oceny liczby zespołów ratowniczych zapewniających skuteczność działań w wyznaczonym rejonie (w tym przypadku wymagany jest dodatkowo opis procesu pojawiania się zdarzeń krytycznych).

Model ten można wykorzystać do analiz prowadzonych metodami:

- klasycznymi - analiza matematyczna;

- Monte Carlo - symulacji czasu poszczególnych etapów reakcji służb ratowniczych według zadanych teoretycznych rozkładów zmiennych losowych;

- wykorzystującymi sieci neuronowe do generacji poszczególnych czasów na podstawie danych historycznych.

Wiarygodność modelu opiera się na dwóch hipotezach, które - przynajmniej częściowo - autorzy postarają się udowodnić w niniejszym artykule:

- empiryczne rozkłady czasu trwania poszczególnych etapów reakcji mogą być wiarygodnie aproksymowane teoretycznymi rozkładami zmiennych losowych;

- parametry i kształt rozkładów opisujących czas trwania poszczególnych etapów reakcji służb ratowniczych są stałe, przynajmniej w kilkuletnich przedziałach czasowych.

Artykuł podzielono na cztery zasadnicze części:

- idea modelu - zaprezentowano w niej główne założenia modelu oraz sposób jego wykorzystania do szacowania: rejonu odpowiedzialności operacyjnej, wskaźnika gotowości zespołów ratowniczych oraz dostępności służb ratowniczych;

- źródło danych - przedstawiono w nim podstawowe parametry bazy danych, z której korzystano podczas badań; 
based on theoretical distributions, including an attempt to prove the hypotheses formulated above;

- model test -the correctness of calculations based on this model were checked with empirical data on defining areas of rescue-team operational responsibility.

\section{The concept underlying the model}

The emergency response process encompasses several key events:

- the dispatcher receives notification of an event (A);

- the rescue teamis assigned the task (B);

- the rescue teams leaves for the scene (C);

- the rescue team reaches the scene and starts rescue operations (D);

- the rescue team ends its operations (E);

- the rescue team returns to the stationing site (F).

All the times between individual events are independent random variables. The main problem, therefore, is to reliably approximate the distributions of these random variables based on theoretical distributions. These distributions can used for further analytical calculations or when employing the Monte Carlo method.

Suppose that we made such an approximation and we know the distributions describing the duration of the various emergency response phases:

- $P\left(t_{A B}\right)$ - the distribution of the random variable describing the dispatcher response time- the time from receiving notification to the moment of dispatching the first rescue team;

- $P\left(t_{B C}\right)$ - the distribution of the random variable describing the time taken by the rescue team to prepare for departure;

- $P\left(t_{D E}\right)$ - the distribution of the random variable describing the rescue operation times.

The distribution of the random variable describing the rescue team's travel time to the scene $\left(t_{c D}\right)$ and its return time after the rescue operation $\left(t_{E F}\right)$ depend on the distance to the scene $(D$ ). The random variable describing this time can be expressed as either the quotient of the distance and the random variable describing the travel speed, or the product of the distance and the random variable describing the time taken to cover one kilometre. The latter solution seems to be more practical for further calculations because it is much easier to add distributions of random variables than to multiply or divide them. Thus, the distribution of the random variable describing travel time to the scene can be described as follows:

$$
P\left(t_{C D}\right)=l \cdot \frac{1}{P(v)}=l \cdot P\left(t_{1 k m}\right)
$$

Hence, for a complete description of emergency response times, it is necessary to determine the distribution describing the time taken by emergency services to cover one kilometre.
- modelowanie czasów cząstkowych - opisano w nim sposoby aproksymacji rozkładów empirycznych (dane historyczne) rozkładami teoretycznymi oraz starano się udowodnić sformułowane powyżej hipotezy;

- test modelu - sprawdzono poprawność obliczeń wykonanych z wykorzystaniem tego modelu z danymi empirycznymi w zakresie określania obszarów operacyjnej odpowiedzialności jednostek ratowniczych.

\section{Idea modelu}

Analiza procesu reakcji służb ratowniczych pozwala wyodrębnić w nim kilka kluczowych zdarzeń:

- przyjęcie zgłoszenia przez dyspozytora (A);

- postawienie zadania zespołom ratowniczym (B);

- wyjazd zespołu ratowniczego do miejsca zdarzenia (C);

- dotarcie zespołu ratowniczego na miejsce zdarzenia i rozpoczęcie czynności ratowniczych (D);

- zakończenie działań ratowniczych (E);

- powrót zespołu ratowniczego do miejsca stacjonowania (F).

Czasy upływające pomiędzy wskazanymi zdarzeniami są niezależnymi zmiennymi losowymi. Głównym zatem problemem jest wiarygodna aproksymacja rozkładów tych zmiennych losowych rozkładami teoretycznymi, które będzie można wykorzystać do dalszych obliczeń analitycznych lub z zastosowaniem metody Monte Carlo.

Załóżmy, że dokonaliśmy takiej aproksymacji i znane nam są rozkłady opisujące czas trwania poszczególnych etapów reakcji służb ratowniczych:

- $P\left(t_{A B}\right)$ - rozkład zmiennej losowej opisującej czas reakcji dyspozytora (czas upływający od przyjęcia zgłoszenia do zadysponowania pierwszego zespołu ratowniczego);

- $\quad P\left(t_{B C}\right)$ - rozkład zmiennej losowej opisującej czas przygotowania zespołu ratowniczego do wyjazdu;

- $\quad P\left(t_{D E}\right)$ - rozkład zmiennej losowej opisującej czas trwania działań ratowniczych.

Rozkład zmiennej losowej opisującej czas przejazdu zespołu ratowniczego do miejsca zdarzenia $\left(t_{C D}\right)$ oraz jego powrotu po zakończeniu działań ratowniczych $\left(t_{E F}\right)$ zależny jest od odległości do miejsca zdarzenia ( $)$. Zmienną losową opisującą ten czas możemy wyrazić za pomocą ilorazu odległości i zmiennej losowej opisującej prędkość przejazdu lub iloczynu odległości i zmiennej losowej opisującej czas pokonania jednego kilometra. Ten drugi sposób wydaje się bardziej praktyczny z punktu widzenia dalszych obliczeń - znacznie łatwiej jest sumować rozkłady zmiennych losowych niż je mnożyć lub dzielić. Uwzględniając powyższe, rozkład zmiennej losowej opisującej czas przejazdu na miejsce zdarzenia możemy zobrazować następująco:

$$
P\left(t_{C D}\right)=l \cdot \frac{1}{P(v)}=l \cdot P\left(t_{1 k m}\right)
$$

Dlatego też do pełnego opisu czasu reakcji służb ratowniczych niezbędne jest określenie rozkładu opisującego czas pokonania jednego kilometra przez służby ratownicze. 
Thus, the distribution of the random variable describing the response time of the rescue system, counted from the moment of receiving notification to the moment in which the first rescue team arrives at the scene, can be described as the sum of random variable distributions:

$P\left(t_{A D}\right)=P\left(t_{A B}\right)+P\left(t_{B C}\right)+l \cdot P\left(t_{1 k m}\right)=P\left(t_{A D} \mid l\right)(2)$

It follows from the formula above that the distribution of the random variable $t_{A D}$ depends on the distance $(I)$ which the rescue teams need to cover. It means that the distribution is conditioned by the distance.

The size of the operational responsibility are is defined by calculating the distance from the boundary of this area $(L)$ to the headquarters of the rescue teams. We assume that the time taken by the rescue team to reach the boundary of the operational responsibility $(L)$ area should be no longer than $T^{2}$ at a predefined confidence level $(\beta)$ for the obtained result. This can be expressed as follows ${ }^{3}$ :

$$
P\left\{t_{A D} \leq T \mid L\right\}=\beta
$$

The confidence level $(\beta)$ should be interpreted as the probability that the rescue team covers the distance $L$ within the specified time $T$. Analyses and regulations concerning State Medical Rescue Services(PRM) [6] indicate that the confidence level $\beta$ should be 0.8 .

Therefore, using the relationship (3), we can determine the distance of the boundary of the operational responsibility area from the headquarters of the rescue teams. However, the use of analytical methods can be quite confusing, especially if the distributions of split times - formula (2) - will be different. In such a case it is much better to apply the Monte Carlo method. In both cases, however, it is necessary to approximate empirical distributions based on theoretical distributions, creating additional uncertainty about the value of the obtained result. To avoid approximation, it would be reasonable to use neural networks that can be trained to generate variables based on historical data. This solution also involves certain errors, but their magnitude can be largely defined during the neural-network training process.

An important element of a successful rescue system is the time taken by the team to prepare for departure. Some rescue teams (State Fire Service - PSP) are permanently on call. The time from when they receive the dispatch instructions to when they leave is fairly short. The preparation times are almost the same across the country due to uniform training methods. However, rescue operations also involve volunteer fire-fighter teams (OSP), where rescuers are not on call at the headquarters twenty-four hours every day. What they do is only declare the time in which they can arrive to the station from when they register alarm. Some of these teams, because of their importance for the fire protection system, are financed from the state

\footnotetext{
2 Recommended time $T$ should be 13 minutes for a fire, 12 minutes for traffic events and 15 minutes for other critical events. See introduction.

3 This means the distribution function of the random variable.
}

A zatem rozkład zmiennej losowej opisującej czas reakcji systemu ratowniczego, liczony od przyjęcia zgłoszenia do dotarcia pierwszego zespołu ratowniczego na miejsce zdarzenia, możemy określić jako sumę rozkładów zmiennych losowych:

$$
P\left(t_{A D}\right)=P\left(t_{A B}\right)+P\left(t_{B C}\right)+l \cdot P\left(t_{1 k m}\right)=P\left(t_{A D} \mid l\right)(2)
$$

Jak wynika z powyższego wzoru rozkład zmiennej losowej $t_{A D}$ jest zależny od odległości (I), na jaką powinien dotrzeć zespół ratowniczy - jest przez nią warunkowany.

Wielkość rejonu odpowiedzialności operacyjnej określamy poprzez wskazanie odległości granicy tego rejonu $(L)$ od siedziby danej grupy zespołów ratowniczych. Zakładamy przy tym, że czas dotarcia zespołu ratowniczego do granicy rejonu odpowiedzialności operacyjnej $(L)$ powinien być nie dłuższy niż $T^{2}$ przy przyjętym poziomie ufności $(\beta)$ dla otrzymanego wyniku, co możemy zapisać ${ }^{3}$ :

$$
P\left\{t_{A D} \leq T \mid L\right\}=\beta
$$

Poziom ufności $(\beta)$ należy interpretować jako prawdopodobieństwo, że zespół ratowniczy dotrze na odległość $L$ nie później niż w zadanym czasie $T$. Z prowadzonych analiz i przepisów prawa dotyczących Państwowego Ratownictwa Medycznego (PRM) [6] wynika, że poziom ufności $\beta$ powinien wynosić 0,8 .

Korzystając zatem z zależności (3), możemy wyznaczyć odległość granicy rejonu odpowiedzialności operacyjnej od siedziby zespołów ratowniczych. Jednakże wykorzystanie metod analitycznych może być dość kłopotliwe zwłaszcza, jeżeli rozkłady czasów cząstkowych - wzór (2) - będą różne. Wówczas znacznie lepszym rozwiązaniem jest zastosowanie metody Monte Carlo. W obu jednak przypadkach wymagana jest aproksymacja rozkładów empirycznych rozkładami teoretycznymi, wprowadzająca dodatkową niepewność co do wartości otrzymanego wyniku. Aby uniknąć aproksymacji, należałoby zastosować sieci neuronowe, które można nauczyć generowania zmiennych na podstawie danych historycznych. Rozwiązanie to również wprowadza pewne błędy, jednakże w trakcie uczenia sieci neuronowych możemy - w znacznym stopniu - definiować ich wielkość.

Istotnym elementem wpływającym na skuteczność systemu ratowniczego jest czas przygotowania zespołu do wyjazdu. Część zespołów ratowniczych (Państwowa Straż Pożarna - PSP) znajduje się w stałej gotowości do wyjazdu. Czas upływający od ich zadysponowania do wyjazdu jest niewielki, a ze względu na sposoby szkolenia niemal jednolity dla całego kraju. Jednakże w działaniach ratowniczych biorą również udział jednostki ochotniczej straży pożarnej (OSP), w których ratownicy nie pełnią całodobowych dyżurów w siedzibie jednostki. Deklarują oni jedynie możliwość dotarcia do siedziby jednostki w określonym czasie od ogłoszenia alarmu. Część tych jednostek - ze względu na ich znaczenie dla systemu ochrony przeciwpożaro-

\footnotetext{
2 Zalecany czas $T$ powinien wynosić 13 min dla pożarów oraz 12 min dla zdarzeń komunikacyjnych oraz 15 min dla innych zdarzeń krytycznych. Zob. wprowadzenie. ${ }^{3}$ This means the distribution function of the random variable.
} 
budget. It is important to select the teams which will best meet the expectations. One of such expectations is, of course, the degree of readiness to act. Using the specified formula [2], it can be concluded that the size of the operational responsibility area largely depends largely on the readiness to act of the rescue teams - it is defined by the amount of time between team dispatch and team departure from the headquarters $\left(t_{B C}\right)$, and depends on whether a complete rescue team can be organised. If, at the time of making the decision, the dispatcher has knowledge about the readiness of individual rescue teams (indicator of readiness to act $-W_{t}$ ), his/her decisions will be more rational. This should help rescue services to operate more effectively and arrive faster at the scene.

The indicator of readiness to act $\left(W_{t}-\right.$ the time needed to organise a complete rescue team, defined with a predefined confidence level) can be estimated based on historical data, provided that it is extensive enough for statistical analysis. However, very often, especially in the case of OSP teams, such data is too scarce. Therefore, we propose that rescuers in each such team determine the most likely time to reach the headquarters in case of alarm. Since such times are measured sporadically (which results in scarcity of historical data), we can assume, a priori, that the arrival time of each rescuer is described using exponential distribution, with a confidence level $(p)$ for the declared time. Based on these assumptions, we can designate the only parameter of this distribution $\lambda$ - the inverse of the scale parameter.

$$
1-e^{-\lambda t}=p \rightarrow \lambda=-\frac{\ln (1-p)}{t}
$$

where:

$\lambda$ - exponential distribution (inverse of the scale);

$t$ - time declared by therescuer to reach the OSP headquarters;

$p$ - confidence level of time to reach the OSP headquarters as declared by the rescuer; the most reliable value is 0.9 - in terms of frequency, it means that in $90 \%$ of cases the rescuer reaches OSP headquarters within the time declared by him/her from the alarm.

The parameter $\lambda$ should be determined individually for each rescuer. The composition of the rescue team depends on the type of vehicle at the disposal of the OSP team. The time in which the team will be ready to leave depends on when the last team member arrives. Hence, the probability of organising a complete team in time $T$ is equal to the probability of the arrival of the last team member to the OSP headquarters:

$$
\begin{aligned}
& W_{T}=P(t \leq T)=\min \left\{P_{1}(t \leq T) ; P_{2}(t \leq T) ;\right. \\
& \left.\ldots ; P_{i}(t \leq T) ; \ldots P_{n}(t \leq T)\right\}
\end{aligned}
$$

where:

$$
P_{i}(t \leq T)=1-e^{-\lambda_{i} \cdot T} \text { - probability of arrival of the } i \text {-last team }
$$
member to the OSP headquarters;

$n$ - number of team members;

$T$ - the expected time taken by the team to prepare for departure. wej - jest dofinansowana z budżetu państwa. Ważną kwestią jest wybór takich jednostek, które najlepiej spełnią oczekiwania. Jednym z nich jest oczywiście stopień gotowości do podjęcia działań ratowniczych. Wykorzystując wskazany schemat (2), możemy stwierdzić, że wielkość rejonu odpowiedzialności operacyjnej zależy w dużej mierze od gotowości zespołu ratowniczego do podjęcia działań - definiuje ją czas upływający od zadysponowania danej jednostki do chwili jej wyjazdu z siedziby $\left(t_{B C}\right)$. Zależy on od możliwości skompletowania zespołu ratowniczego. Jeżeli w chwili podejmowania decyzji dyspozytor będzie posiadał wiedzę na temat gotowości poszczególnych zespołów ratowniczych (wskaźnik gotowości do działania $-W_{t}$ ), jego decyzje będą bardziej racjonalne. Powinno się to przyczynić do większej skuteczności działania służb ratowniczych - szybszego ich dotarcia na miejsce zdarzenia.

Wskaźnik gotowości do działania $\left(W_{t}\right.$ - czas skompletowania zespołu ratowniczego określony z zadanym poziomem ufności) możemy oszacować na podstawie danych historycznych pod warunkiem, że ich ilość będzie odpowiednia do analiz statystycznych. Jednakże bardzo często - szczególnie w przypadku dysponowania jednostek OSP - tych danych jest zbyt mało. Dlatego proponujemy, aby ratownicy każdej takiej jednostki określili najbardziej prawdopodobny czas dotarcia do jej siedziby w przypadku ogłoszenia alarmu. Ze względu na sporadyczność sprawdzania tego czasu (małą ilość danych historycznych) możemy przyjąć a priori, że czas dotarcia poszczególnych ratowników jest opisany rozkładem wykładniczym, przyjmując jednocześnie poziom ufności (p) dla deklarowanego czasu. Poczynione założenia pozwalają wyznaczyć jedyny parametr tego rozkładu $\lambda$ - odwrotność parametru skali.

$$
1-e^{-\lambda t}=p \rightarrow \lambda=-\frac{\ln (1-p)}{t}
$$

gdzie:

$\lambda$ - parametr rozkładu wykładniczego (odwrotność skali);

$t$ - deklarowany przez ratownika czas dotarcia do siedziby OSP;

p - poziom ufności dla deklarowanego przez ratownika czasu dotarcia do siedziby OSP; najbardziej wiarygodna jego wartość to 0,9-w ujęciu częstościowym oznacza, że w $90 \%$ przypadków ratownik dotrze do siedziby OSP nie później niż w deklarowanym przez siebie czasie od chwili ogłoszenia alarmu.

Parametr $\lambda$ należy wyznaczyć dla każdego ratownika indywidualnie. Skład zespołu ratowniczego uzależniony jest od rodzaju pojazdu, jakim dysponuje dana jednostka OSP. Czas, w jakim jego załoga będzie gotowa do wyjazdu, zależy od czasu przybycia ostatniego jej członka. Stąd też prawdopodobieństwo skompletowania załogi w czasie $T$ jest równe prawdopodobieństwu przybycia do siedziby OSP ostatniego z członków danego zespołu:

$$
\begin{aligned}
& W_{T}=P(t \leq T)=\min \left\{P_{1}(t \leq T) ; P_{2}(t \leq T) ;\right. \\
& \left.\ldots ; P_{i}(t \leq T) ; \ldots P_{n}(t \leq T)\right\}
\end{aligned}
$$


When a given OSP team has the ability to dispatch several rescue teams (it has several fire engines), there will be a few readiness indicators, calculated for each team individually.

The readiness indicator [2] $W_{T}=P(t \leq T)$ can be standardised, defining the obligatory value of $T$. Based on the study results, the best option is to define the time $T$ at 5 minutes. If the longest time declared by the members of the rescue team is 5 minutes, the readiness indicator $P(t \leq T)$ will be 0.9 , and the team will be able to respond to events which are $3 \mathrm{~km}$ away from the OSP headquarters with a $90 \%$ efficiency ${ }^{4}$. The efficiency will increase as the distance decreases. Table 1 presents more detailed sizes of operational responsibility areas depending on the rescue-team readiness indicator. gdzie:

$P_{i}(t \leq T)=1-e^{-\lambda_{i} \cdot T}$ - prawdopodobieństwo dotarcia $i$-tego członka załogi do siedziby OSP;

$n$ - liczba członków załogi;

$T$ - oczekiwany czas gotowości zespołu do wyjazdu.

W przypadku, gdy dana jednostka OSP posiada zdolność do wystawienia kilku zespołów ratowniczych (dysponuje kilkoma pojazdami pożarniczymi), wskaźników gotowości będzie kilka, liczonych dla każdego zespołu indywidualnie.

Wskaźnik gotowości [2] $W_{T}=P(t \leq T)$ można zestandaryzować, przyjmując obligatoryjnie wartość $T$. Opierając się na wynikach badań, najlepszym rozwiązaniem jest przyjęcie czasu $T$ na poziomie 5 min. Jeżeli najdłuższy zadeklarowany przez członków zespołu ratowniczego czas wyniesie $5 \mathrm{~min}$, to wówczas wskaźnik gotowości $P(t \leq T)$ osiągnie wartość 0,9 , a zespół ten będzie zdolny do reagowania na zdarzenia odległe o $3 \mathrm{~km}$ od siedziby OSP z 90\% skutecznością ${ }^{4}$. Będzie ona rosła wraz ze zmniejszaniem się tej odległości. Bardziej szczegółową wielkość obszarów odpowiedzialności operacyjnej w zależności od wskaźnika gotowości zespołów ratowniczych przedstawiono w tabeli 1.

Table. 1. The operational responsibility area of OSP teams depending on the standardised indicator of personnel readiness and the confidence level for the obtained result

Tabela 1. Obszar odpowiedzialności operacyjnej Jednostki OSP w zależności od standaryzowanego wskaźnika gotowości zasobów osobowych oraz poziomu ufności dla otrzymanego wyniku

\begin{tabular}{ccc}
\hline $\begin{array}{c}\text { Standardised indicator of personnel readiness } \\
\text { (in brackets - the longest time of arrival } \\
\text { declared by a team member) }\end{array}$ & $\begin{array}{c}\text { Size of operational responsibility area (L) } \\
\text { at a confidence level of } 0.9 \text { [km] }\end{array}$ & $\begin{array}{c}\text { Size of operational responsibility area (L) } \\
\text { at a confidence level of } 0.8 \text { [km] }\end{array}$ \\
$\begin{array}{c}\text { Standaryzowany wskaźnik gotowości zasobów } \\
\text { osobowych (w nawiasie najdłuższy czas przybycia } \\
\text { deklarowany przez członka zespołu) }\end{array}$ & $\begin{array}{c}\text { Wielkość obszaru odpowiedzialności operacyjnej (L) } \\
\text { przy poziomie ufności } 0,9[\mathrm{~km}]\end{array}$ & $\begin{array}{c}\text { Wielkość obszaru } \\
\text { odpowiedzialności operacyjnej (L) } \\
\text { przy poziomie ufności } 0,8 \text { [km] }\end{array}$ \\
\hline $0.9(5 \mathrm{~min})$ & 3 \\
\hline $0.85(6 \mathrm{~min})$ & 2.5 \\
\hline $0.8(7 \mathrm{~min})$ & 2 \\
\hline $0.76(8 \mathrm{~min})$ & 1.3 \\
\hline $0.7(9 \mathrm{~min})$ & 0.5 \\
\hline
\end{tabular}

Source: Own elaboration

Źródło: Opracowanie własne.

Another problem, as mentioned in the introduction, is the number of rescue teams required to make an effective response within the operational responsibility area of the fire protection team. Underlying this problem can be the following question: What is the probability of another call being made when all rescue teams are conducting rescue operations? To solve this problem, we need to know the process describing the emergence of additional events in the operational responsibility area of the rescue team. Since such events occur sporadically, it can be assumed that the waiting time for the next event is described

\footnotetext{
${ }^{4}$ Data comes from research conducted as part of the project mentioned earlier.
}

Kolejnym problemem, zasygnalizowanym we wprowadzeniu, jest niezbędna liczba zespołów ratowniczych zapewniająca skuteczną reakcję dla obszaru odpowiedzialności operacyjnej wskazanej jednostki ochrony przeciwpożarowej. Zagadnienie to możemy sprowadzić do pytania: jakie jest prawdopodobieństwo pojawienia się kolejnego zgłoszenia w trakcie prowadzenia działań ratowniczych przez wszystkie zespoły ratownicze? Rozwiązanie tego problemu wymaga znajomości procesu opisującego pojawianie się kolejnych zdarzeń na obszarze odpowiedzialności operacyjnej danej jednostki ratowniczej. Ze względu na sporadyczność takich zdarzeń można przyjąć, że czas oczekiwania na

\footnotetext{
${ }_{4}$ Dane te pochodzą z badań prowadzonych w ramach wspomnianego projektu.
} 
by exponential distribution ${ }^{5}$. The basic parameter of this distribution is the expected number of events per unit of time $(\mu)$. Suppose that we know the expected number of events per unit of time in the operational responsibility area, and we know the distribution describing the rescue operation times - from when the dispatcher receives the call to when the rescue team returns to the headquarters. It can be determined using the following equation:

$$
P\left(t_{A F}\right)=P\left(t_{A B}\right)+P\left(t_{B C}\right)+P\left(t_{D E}\right)+2 \cdot l \cdot P\left(t_{1 k m}\right)
$$

The rescue operation time $\left(t_{A F}\right)$ can be determined from the distribution function $\mathrm{P}\left(\mathrm{t}_{\mathrm{AF}}\right)$, at a confidence level $\mathrm{Y}$ for the obtained result:

$$
P\left\{t_{A F} \leq t_{r}\right\}=\gamma
$$

From the above formula, we calculatethe value of $t_{R^{\prime}}$ and then we determine the probability of at least one event occurring at this time using the equation:

$$
p=P\{k>0\}=1-e^{-\mu \cdot t_{R}}
$$

If probability $p$ is at an acceptable level, it can be assumed that the number of rescue teams in the operational responsibility area is sufficient. The presented calculations refer to a situation where in a particular area there is only one rescue team. The aim was to indicate the idea of such calculations. However, to assess their availability the classification of critical events should be made due to the number of rescue teams involved in rescue operations. After making such a classification and estimating parameter $\mu$ for each class of events, estimating availability of a larger number of rescue teams operating in their operational responsibility area does not cause undue difficulties.

The above concept of describing emergency response times and its general applicability was verified as part of studies based on the example of historical data from several districts located in different Polish provinces. We used data concerning the operations of one of the emergency services - the State Fire Service. The main problem that was solved in the course of our studies was to provide a stochastic description of the durations of individual stages of emergency response to events, and to validate this description.

\section{Source of data}

During our studies, we used the accessible part of the SWDST 2.5 system database. It is an integrated system designed to use information from various databases to support the work of

\footnotetext{
5 This hypothesis has been proven in the course of studies conducted as part of this project. It has been shown that the emergence of events is, in the long term, a stationary exponential process. See [3].
}

kolejne zdarzenie opisany jest rozkładem wykładniczym ${ }^{5}$. Podstawowym parametrem tego rozkładu jest oczekiwana liczba zdarzeń w jednostce czasu $(\mu)$. Załóżmy, że znamy oczekiwaną liczbę zdarzeń w jednostce czasu na danym obszarze odpowiedzialności operacyjnej oraz znamy rozkład opisujący czas prowadzenia działań ratowniczych - od chwili przyjęcia zgłoszenia przez dyspozytora do czasu powrotu jednostki ratowniczej do siedziby. Możemy go wyznaczyć z zależności:

Czas prowadzenia działań ratowniczych ( $\left.t_{A F}\right)$ możemy wyznaczyć $z$ dystrybuanty rozkładu $\mathrm{P}\left(\mathrm{t}_{\mathrm{AF}}\right)$, przyjmując poziom ufności y dla otrzymanego wyniku:

$$
P\left\{t_{A F} \leq t_{r}\right\}=\gamma
$$

Za pomocą powyższego wzoru obliczamy wartość $t_{R^{\prime}}$ a następnie wyznaczamy prawdopodobieństwo pojawienia się przynajmniej jednego zdarzenia w tym czasie z zależności:

$$
p=P\{k>0\}=1-e^{-\mu \cdot t_{R}}
$$

Jeżeli prawdopodobieństwo $p$ sytuuje się na akceptowalnym poziomie, można przyjąć, że liczba zespołów ratowniczych w danym rejonie odpowiedzialności operacyjnej jest wystarczająca. Wskazane obliczenia odnoszą się do sytuacji, gdy w danym obszarze działa tylko jeden zespół ratowniczy. Chodziło o wskazanie idei takich obliczeń. Większa liczba zespołów ratowniczych nie stanowi problemu, jednakże do oceny ich dostępności należy dokonać klasyfikacji zdarzeń krytycznych ze względu na liczbę zaangażowanych w działania ratownicze zespołów. Po dokonaniu takiej klasyfikacji oraz obliczeniu parametru $\mu$ dla każdej klasy zdarzeń, oszacowanie dostępności dla większej liczby zespołów ratowniczych działających w danym rejonie operacyjnej odpowiedzialności nie nastręcza zbytnich trudności.

Wskazana powyżej idea opisu czasu reakcji służb ratowniczych wraz z zasadniczymi możliwościami jej wykorzystania została sprawdzona w ramach prowadzonych badań na przykładzie danych historycznych pochodzących z kilku powiatów znajdujących się w różnych województwach. Korzystano z danych dotyczących działania jednej ze służb ratowniczych - Państwowej Straży Pożarnej. Zasadniczym problemem, który rozwiązywano w trakcie badań, jest opis stochastyczny czasów trwania poszczególnych etapów procesu reagowania służb ratowniczych na zaistniałe zdarzenia oraz uzasadnienie wiarygodności tego opisu.

\section{Źródło danych}

W trakcie badań korzystano z udostępnionej części bazy systemu SWD-ST 2,5. Stanowi on zintegrowany system informatyczny, którego celem jest wykorzystanie informacji zawartych

\footnotetext{
Hipoteza ta została udowodniona w trakcie badań prowadzonych w ramach wspomnianego projektu. Wykazano w nich, że proces pojawiania sie zdarzeń jest stacjonarnym, w perspektywie kilku lat, procesem wykładniczym. Zob. [3].
} 
the State Fire Service on all administrative levels. It also facilitates automated exchange of information between various head quarters and possibly other services. A detailed description of the system's functionalities and the scope of data collected and processed using it includes: SWD-ST 2.5 System User Guide, released by Akabus Systemy Teleinformatyczne Sp. z o.o. in 2013.

Each critical incident is recorded in this system in terms of: space, time, deployed manpower and resources, consequences for life and health of the victims and rescuers, nature and causes of the events. This system allows to receive calls in real-time and handle events by organising personnel and resources of the State Fire Service and Volunteer Fire Brigades operating under the National Fire and Rescue (KSRG) and beyond.

In spatial, the system includes: WGS 84 event location coordinates; event address - commune, town/city/village, street and number of kilometres covered by the rescue team. Categories of events are recorded by: type (fire, local hazards) and severity (minor, moderate, major). Additionally, a description is provided of the underlying causes. Time-related data that are collected include: time of identification, location and elimination of the event, as well as the time taken to dispatch a rescue team and the time it takes to arrive at the scene and return to the station. Time data is given accurate to one minute. In terms of deployed manpower and resources, data include deployed manpower and resources, taking into account the type of equipment. The User Guide mentioned above includes a detailed list of data stored in the system.

\section{Approximation of response times based on empirical data}

Empirical distributions can be directly obtained from data included in the SWD-ST 2.5database for the following random variables:

- dispatcher response time- $t_{A B^{i}}$

- rescue operation time $-t_{D E}$.

Time distributions of preparation for departure $\left(t_{B C}\right)$ and covering the distance of $1 \mathrm{~km}\left(t_{l k m}\right)$ can be obtained by indirect methods, because the database contains only the total time from rescue-team dispatch to arrival at the scene.

Due to editorial constraints, this article presents data on the operations of PSP in just one district in the years 2006-2011. However, as mentioned above, our studies included several districts. Their results are consistent with those presented in this article.

Distributions describing the times taken by individual emergency response stages can be approximated in several ways, including:

- by assuming, a priori, the shape of probability distribution for each variable and estimating its parameters based on empirical data or expert assessment;

- by choosing the shape and parameters of the distribution of a random variable based on empirical data. w bazach danych do wspomagania pracy Państwowej Straży Pożarnej na wszystkich poziomach administracyjnych. Pozwala on również na automatyczną wymianę informacji między poszczególnymi Komendami i ewentualnie innymi służbami. Szczegółowy opis funkcjonalności oraz zakresu gromadzonych i przetwarzanych danych tego systemu zawiera: Podręcznik użytkownika Systemu SWD-ST 2.5, wydany przez Akabus Systemy Teleinformatyczne Sp. z o.o. 2013.

W systemie tym rejestrowane są poszczególne incydenty krytyczne w zakresie: przestrzennym, czasowym, użytych sił i środków, skutków dla życia i zdrowia ofiar zdarzenia oraz ratowników, rodzaju i przyczyn zdarzenia. Narzędzie pozwala w czasie rzeczywistym przyjmować zgłoszenia oraz obsługiwać zdarzenia w zakresie dysponowania sił i środków Państwowej Straży Pożarnej oraz Ochotniczych Straży Pożarnych funkcjonujących w ramach KSRG i poza nim.

W zakresie przestrzennym ujmuje się w nim: współrzędne geograficzne miejsca zdarzenia w układzie WGS 84; adres zdarzenia - gmina, miejscowość, ulica oraz liczba kilometrów przebytych przez jednostkę. Kategorie zdarzeń uwzględnia się w postaci: rodzaju (pożar, zagrożenia miejscowe); wielkości (małe, średnie, duże), uzupełnieniem tych informacji są wskazane opisowo przyczyny zdarzenia. W obszarze czasowym gromadzi się następujące dane: czas zauważenia, lokalizacji i usunięcia zdarzenia oraz czas zadysponowania jednostki ratowniczej, dotarcia jej do miejsca zdarzenia i powrotu ostatniej jednostki. Dane czasowe podawane są z dokładnością do jednej minuty. W zakresie użytych sił i środków podawane są zadysponowane siły i środki z uwzględnieniem rodzaju sprzętu. Szczegółowy wykaz danych gromadzonych w systemie zawiera wspomniany powyżej Podręcznik użytkownika.

\section{Aproksymacja czasów reakcji na podstawie danych empirycznych}

Z danych ujętych w bazie SWD-ST 2,5 można pozyskać bezpośrednio rozkłady empiryczne następujących zmiennych losowych:

- czas reakcji dyspozytora $-t_{A B^{\prime}}$;

- czas prowadzenia działań ratowniczych $-t_{D E}$.

Natomiast rozkłady czasu: przygotowania do wyjazdu $\left(t_{B C}\right)$ oraz pokonania $1 \mathrm{~km}\left(t_{l \mathrm{~km}}\right)$ można uzyskać metodami pośredni$\mathrm{mi}$, ponieważ w bazie zapisany jest jedynie łączny czas liczony od zadysponowania zespołu ratowniczego do jego dotarcia na miejsce zdarzenia.

W artykule przedstawiono dane dotyczące działania PSP na terenie jednego tylko powiatu w latach 2006-2011 ze względu na ograniczenia redakcyjne. Jednakże $w$ badaniach, jak już wspomniano, uwzględniono kilka powiatów. Ich wyniki są zgodne z prezentowanymi w niniejszym artykule.

Aproksymacji rozkładów opisujących czas poszczególnych etapów procesu reagowania zespołów ratowniczych można dokonać kilkoma metodami:

- zakładając a priori kształt rozkładu prawdopodobieństwa dladanejzmiennejiszacującjego parametrynapodstawie danych empirycznych lub oceny ekspertów;

- dobierając kształt i parametry rozkładu zmiennej losowej na podstawie danych empirycznych. 
The second method is inherently more accurate and more obvious. However, it requires reliable and adequate data. What is more, most empirical distributions are significantly different from theoretical distributions in terms of shape. Hence, their approximation creates an area of uncertainty for the formulated conclusions. A similar area of uncertainty occurs in the first method of approximation. The shape of approximating distributions is usually selected based on the characteristics of the phenomena investigated. And its parameters are selected based on empirical data, if adequate data is available, or based on expert assessment.

The time taken by individual emergency response stages depends on many random factors. It appears, then, that normal distribution is the most suitable for their approximation, also due to its properties. The density of probability for this distribution can be expressed in the following manner (see [7]):

$$
\phi(x \mid \mu, \sigma)=\frac{1}{\sigma \sqrt{2 \pi}} \cdot \exp \left[-\frac{(\mathrm{x}-\mu)^{2}}{2 \sigma^{2}}\right]
$$

If we have less data or use only expert opinions, its parameters can be estimated using PERT (program evaluation and review technique). According to this method, distributions with the random-variable parameters of: minimum value $\left(t_{0}\right)$, maximum value $\left(t_{m}\right)$ and mode $\left(t_{d}\right)$ can be essentially approximated by normal distribution with the following parameters (see [5]):

$$
\begin{aligned}
& \text { - expected value: } \mu=\frac{t_{o}+4 \cdot t_{d}+t_{m}}{6} ; \\
& \text { - standard deviation: } \sigma=\frac{t_{m}-t_{o}}{6} .
\end{aligned}
$$

Another distribution that can be taken into account is a lognormal distribution. It provides a much better description of how long it takes to perform individual operations. As such, it is probably a more useful measure to describe dispatcher response and team preparation times. A log-normal distribution is a normal distribution of a random-variable logarithm, whose density of probability is given by (see [1]):

$$
\phi(\ln x \mid \mu, \sigma)=\frac{1}{x \sigma \sqrt{2 \pi}} \cdot \exp \left[-\frac{(\ln (x)-\mu)^{2}}{2 \sigma^{2}}\right]
$$

In the calculations presented below, we used data based on the second of the discussed approximation methods.

\section{Response time of the dispatcher}

When collecting data for the analysis of dispatcher response times, we took into account all the events that happened in the studied district in the years 2006-2011. The dispatcher response time is accurate to 1 minute. It should be kept in mind, then, that a response time of 2 means that the actual response time was more than, or equal to, 2 minutes and less than 3 minutes. Because of the method of recording data in the source
Drugi sposób jest ze swej natury dokładniejszy i bardziej oczywisty, jednakże wymaga on rzetelnych danych w dostatecznej ilości. Ponadto większość rozkładów empirycznych znacznie odbiega kształtem od rozkładów teoretycznych. Stąd też ich aproksymacja generuje pewien obszar niepewności dla formułowanych wniosków. Podobny obszar niepewności uzyskujemy przy pierwszym sposobie aproksymacji. Kształt rozkładów aproksymujących dobieramy zazwyczaj na podstawie cech charakteryzujących zjawiska, natomiast jego parametry - na podstawie danych empirycznych, jeżeli posiadamy je w odpowiedniej ilości lub na podstawie oceny ekspertów.

Czas trwania poszczególnych etapów reakcji służb ratowniczych zależy od bardzo wielu przypadkowych czynników. Wydaje się zatem, że do ich aproksymacji najlepiej nadaje się rozkład normalny, również ze względu na posiadane własności. Gęstość prawdopodobieństwa dla tego rozkładu opisana jest wzorem (zob. [7]):

$$
\phi(x \mid \mu, \sigma)=\frac{1}{\sigma \sqrt{2 \pi}} \cdot \exp \left[-\frac{(\mathrm{x}-\mu)^{2}}{2 \sigma^{2}}\right]
$$

Jeżeli posiadamy mniejszą ilość danych lub korzystamy jedynie z opinii ekspertów, jego parametry możemy oszacować wykorzystując metodę PERT (Program Evaluation and Review Technique). Zgodnie z istotą tej metody rozkład o parametrach zmiennej losowej: wartość minimalna $\left(t_{0}\right)$, wartość maksymalna $\left(t_{m}\right)$ oraz dominanta $\left(t_{d}\right)$ można aproksymować rozkładem normalnym o parametrach (zob. [5]):

$$
\begin{aligned}
& \text { - wartość oczekiwana: } \mu=\frac{t_{o}+4 \cdot t_{d}+t_{m}}{6} \text {; } \\
& \text { - odchylenie standardowe: } \sigma=\frac{t_{m}-t_{o}}{6} \text {. }
\end{aligned}
$$

Drugim rozkładem, który może być brany pod uwagę jest rozkład logarytmicznie normalny. Znacznie lepiej opisuje on czas wykonywania czynności przez ludzi. Prawdopodobnie będzie on zatem przydatniejszy do opisu czasu reakcji dyspozytora czy też czasu przygotowania zespołu do wyjazdu. Rozkład logarytmicznie normalny to rozkład normalny logarytmu zmiennej losowej, którego gęstość prawdopodobieństwa określona jest wzorem (zob. [1]):

$$
\phi(\ln x \mid \mu, \sigma)=\frac{1}{x \sigma \sqrt{2 \pi}} \cdot \exp \left[-\frac{(\ln (x)-\mu)^{2}}{2 \sigma^{2}}\right]
$$

W prezentowanych poniżej obliczeniach korzystanoz danych, stosując drugą ze wskazanych metod aproksymacji.

\section{Czas reakcji dyspozytora}

Pozyskując dane do analizy czasu reakcji dyspozytora, uwzględniono wszystkie zdarzenia, jakie miały miejsce na terenie badanego powiatu w latach 2006-2011. Czas reakcji dyspozytora wskazywany jest z dokładnością do 1 minuty. Należy zatem pamiętać, że czas reakcji równy 2 oznacza, że faktyczny czas reakcji był większy bądź równy 2 min i mniejszy od 3 min. Ze względu na sposób zapisu danych w bazie źródłowej przy 
database, the middle, and not the left limit, was included in the analysis. If the value recorded in the database was $0 \mathrm{~min}$, we assumed it was $0.5 \mathrm{~min}$; if the value was 1 , we assumed it was $1.5 \mathrm{~min}$, etc.

Table 2 shows the parameters for empirical distributions of dispatcher response times. As we can see, the distribution is significantly right-skewed and strongly concentrated around the mode. Judging by its kurtosis and skewness, it is similar to a log-normal distribution. To better illustrate its shape, figure 1 shows the points of beginning of dispatcher response time histograms in respective years. For the sake of clarity, the histograms are presented as continuous functions. analizie przyjęto następującą zasadę: w analizach uwzględniono środek przedziału, a nie jego lewą granicę. Jeżeli wartość zapisana w bazie wynosiła 0 min, to przyjmowano wartość 0,5 min, jeżeli była to natomiast wartość 1, to przyjmowano 1,5 min itd.

Parametry empirycznych rozkładów czasu reakcji dyspozytora przedstawiono $w$ tabeli 2 . Jak łatwo zauważyć, rozkład ten charakteryzuje się znaczną prawoskośnością oraz silnym skoncentrowaniem wokół dominanty. Sądząc po kurtozie i skośności, jest on zbliżony do rozkładu logarytmicznie normalnego. Dla lepszego zobrazowania jego kształtu na rycinie 1 przedstawiono początek histogramów czasu reakcji dyspozytora w poszczególnych latach. Dążąc do wzrostu czytelności histogramów, przedstawiono je jako funkcje ciągłe.

Table 2. Parameters for empirical distributions of dispatcher response times in minutes - from when the call is received to when the first rescue team is dispatched (2006-2011)

Tabela 2. Parametry rozkładów empirycznych czasu reakcji dyspozytora w min - od przyjęcia zgłoszenia do zadysponowania pierwszego zespołu ratowniczego w poszczególnych latach 2006-2011

\begin{tabular}{|c|c|c|c|c|c|c|}
\hline & 2006 & 2007 & 2008 & 2009 & 2010 & 2011 \\
\hline Average / Średnia & 5.93 & 3.93 & 4.24 & 4.12 & 4.63 & 3.90 \\
\hline Standard error / Błąd standardowy & 0.21 & 0.19 & 0.19 & 0.18 & 0.15 & 0.17 \\
\hline Median / Mediana & 4.5 & 2.5 & 2.5 & 2.5 & 3.5 & 2.5 \\
\hline Mode / Dominanta & 2.5 & 2.5 & 2.5 & 2.5 & 2.5 & 2.5 \\
\hline Standard deviation / Odchylenie standardowe & 4.62 & 4.15 & 4.27 & 3.70 & 3.52 & 3.55 \\
\hline Sample variance / Wariancja próbki & 21.33 & 17.23 & 18.20 & 13.68 & 12.41 & 12.61 \\
\hline Kurtosis / Kurtoza & 5.72 & 11.58 & 6.23 & 11.00 & 5.23 & 19.03 \\
\hline Skewness / Skośność & 2.17 & 3.01 & 2.29 & 2.92 & 2.06 & 3.93 \\
\hline Minimum & 0.5 & 0.5 & 0.5 & 0.5 & 0.5 & 1.5 \\
\hline Maximum / Maksimum & 30.5 & 30.5 & 30.5 & 27.5 & 25.5 & 30.5 \\
\hline Counter / Licznik & 477 & 469 & 481 & 424 & 577 & 416 \\
\hline
\end{tabular}

Source: Own elaboration based on data from the SWD-ST 2.5 database.

Źródło: Opracowanie własne na podstawie danych z Bazy SWD-ST 2,5.

Data analysis indicates a strong concentration around the modes. For all the years, the value is the same $-2.5 \mathrm{~min}$. This partially confirms the hypothesis formulated in the introduction about the stability of parameters and the shape of these distributions at several-year intervals. This property can be used to design or reorganise emergency services.

Due the significant right-skewness of the distributions, their approximation by a normal distribution is not viable. The presented histogram (figure 1) indicates that the analysed empirical distribution is bimodal, or even trimodal. It is difficult to determine the cause of this phenomenon from the collected data. Potentially, this may be related to how well trained individual dispatchers are, or to the complexity of events. The multimodality of an empirical distribution excludes its compatibility with any theoretical distribution. However, in order for the further discus-
Analiza prezentowanych danych wskazuje na silną koncentrację wokół dominanty. Dla wszystkich lat jej wartość jest taka sama - 2,5 min. Potwierdza to częściowo - sformułowaną we wprowadzeniu - hipotezę o stałości parametrów i kształtu tych rozkładów w kilkuletnich przedziałach czasowych. Własność tę można wykorzystać do projektowania lub reorganizacji systemu służb ratowniczych.

Znaczna prawoskośność rozkładów wyklucza ich aproksymację rozkładem normalnym. Zaprezentowany histogram (rycina 1) wskazuje na dwumodalność, czy wręcz nawet trójmodalność, analizowanego rozkładu empirycznego. na podstawie zebranych danych trudno jest określić przyczynę tego zjawiska. Należy raczej sądzić, że może być ono związane ze stopniem wyszkolenia poszczególnych dyspozytorów lub stopniem komplikacji zgłaszanych spraw. Wielomodalność rozkładu empirycz- 
sions in this article to be meaningful, approximation using theoretical distribution is necessary. The shapes of the histograms show a significant semblance to a log-normal distribution. Hence, this type of distribution was used for approximation.

Its parameters are based on:

- all data;

- and on the basis of data from the $0.05-0.85$ percentile intervalof the empirical distribution.

The approximating distribution with parameters determined using the second method is closer to an empirical distribution. nego wyklucza jego zgodność z jakimkolwiek rozkładem teoretycznym. Jednakże, aby dalsze rozważania nad problematyką prezentowaną w niniejszym artykule miały sens, należy dokonać jego aproksymacji rozkładem teoretycznym. Kształt histogramów wskazuje na istotne podobieństwo do rozkładu logarytmicznie normalnego. Taki też rozkład został wykorzystany do aproksymacji. Jego parametry wyznaczono na podstawie:

- wszystkich danych;

- na podstawie danych pochodzących z przedziału percentyl $(0,05)$ - percentyl $(0,85)$ rozkładu empirycznego.

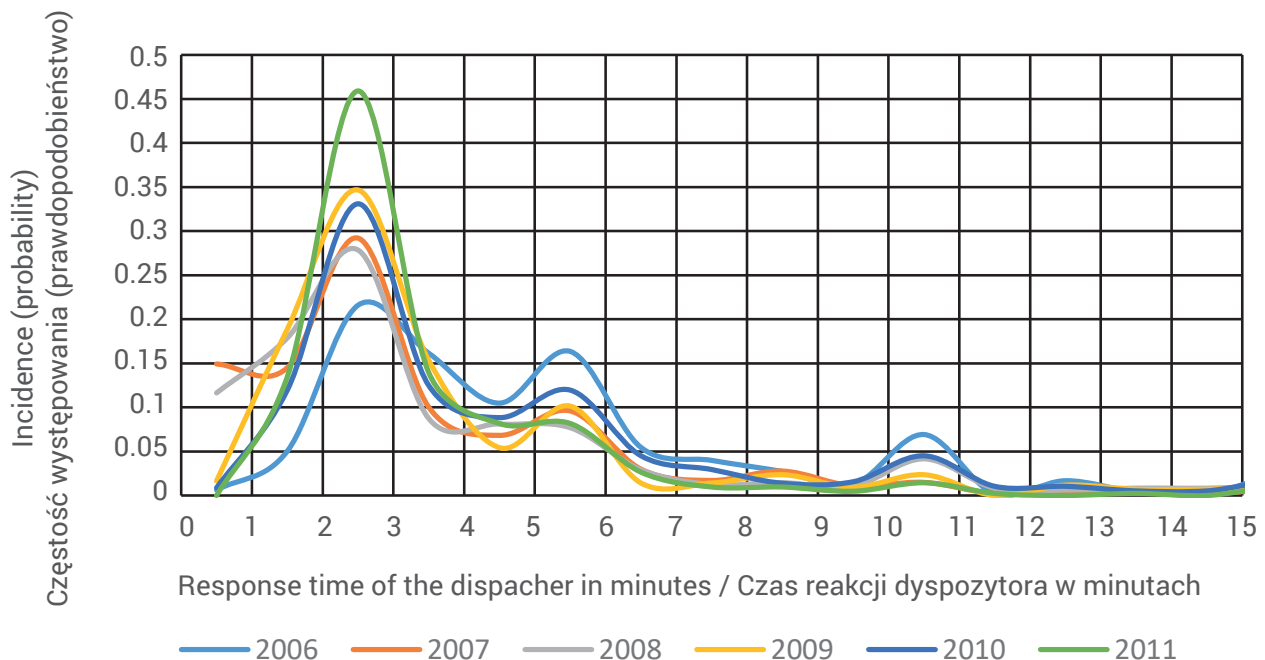

Figure 1. Histograms ofdispatcher response times (2006-2011)

Rycina 1. Histogramy czasu reakcji dyspozytora w poszczególnych latach 2006-2011

Source: Own elaboration based on data from the SWD-ST 2.5 database.

Źródło: Opracowanie własne na podstawie danych z Bazy SWD-ST 2,5.

This is presented in Figure 2. For reasons explained above, this article does not include any tests for compliance between the approximating distribution and the empirical distribution, since their results are negative. The correctness of the approximation was presented only visually, in Figure 2, as histograms of empirical distributions from the years 2009-2011, and of a log-normal distribution, whose parameters were determined based on data from 2009. This strong compliance in Figure 2 does not apply to every year, as reflected in Figure 3. However, we believe that it is good enough to simulate dispatcher response times, necessary for the design or reorganisation of the emergency services.

The approximation was done using a logarithm of dispatcher response times and by determining its fundamental measures for the resulting empirical distribution. This was done under the assumption that the resulting distribution was a normal distribution. Table 3 shows the basic parameters of the distribution of variable $y=\ln \left(t_{A B}\right)$ in the years 2006-2011 for the district under study.
Rozkład aproksymujący o parametrach wyznaczonych tym drugim sposobem jest bardziej zbliżony do rozkładu empirycznego, co zaprezentowano na rycinie 2 . Z oczywistych względów (wspomnianych powyżej), nie zamieszczono w artykule żadnych testów na zgodność rozkładu aproksymującego z rozkładem empirycznym, ponieważ dają one wynik negatywny. Poprawność aproksymacji pokazana została jedynie wizualnie na rycinie 2 . Zamieszczono na nim histogramy rozkładów empirycznych z lat 2009-2011 oraz rozkładu logarytmicznie normalnego, którego parametry wyznaczono $w$ oparciu o dane z roku 2009. Widoczna na rycinie 2 zgodność nie w każdym roku jest taka wysoka, co odzwierciedla rycina 3. Niemniej jednak, zdaniem autorów, jest wystarczająco dobra do prowadzenia symulacji czasu reakcji dyspozytora, niezbędnych przy projektowaniu bądź reorganizacji systemu służb ratowniczych.

Aproksymacji dokonano, logarytmując czas reakcji dyspozytora oraz wyznaczając dla tak powstałego rozkładu empirycznego podstawowe jego miary przy założeniu, że utworzony rozkład jest rozkładem normalnym. W tabeli 3 przedstawiono podstawowe parametry rozkładu zmiennej $y=\ln \left(t_{A B}\right)$ w latach 2006-2011 dla badanego powiatu. 
The presented results indicate a strong stability of the shape and the parameters of empirical distributions for dispatcher response times at intervals of several years. This property can be used for making predictions several years into the future, based on data from previous years. Such predictions could be used to optimise the capabilities and deployment of emergency services. However, this would require the remaining response stages to demonstrate a similar property. Moreover, it would be necessary to know the spatial distribution of hazards for which this system is built. There is strong documented evidence that the spatial distribution of local hazards is also stable over a horizon of several years ${ }^{6}$.

The closest theoretical distribution that describes dispatcher response times is a log-normal distribution, whose parameters are estimated based on empirical data from the $0.05-0.85$ percentile interval.
Zaprezentowane wyniki badań wskazują na znaczną stałość kształtu i parametrów rozkładów empirycznych czasu reakcji dyspozytora w kilkuletnich przedziałach czasowych. Własność ta może być wykorzystana do prognozowania w kilkuletniej perspektywie w oparciu o dane z lat poprzednich. Możliwość ta otwiera drogę do optymalizacji potencjału i rozmieszczenia służb ratowniczych. Aby jednak było to możliwe, pozostałe etapy procesu reagowania muszą wykazywać podobną własność oraz należy znać przestrzenny rozkład zagrożeń, dla których ów system jest budowany. Istnieją silnie udokumentowane przesłanki, że przestrzenny rozkład zagrożeń miejscowych jest również stabilny w kilkuletniej perspektywie czasowej ${ }^{6}$.

Najbardziej zbliżonym rozkładem teoretycznym opisującym czas reakcji dyspozytora jest rozkład logarytmicznie normalny, którego parametry oszacowane zostały na podstawie danych empirycznych z przedziału: percentyl $(0,05)$ - percentyl $(0,85)$.

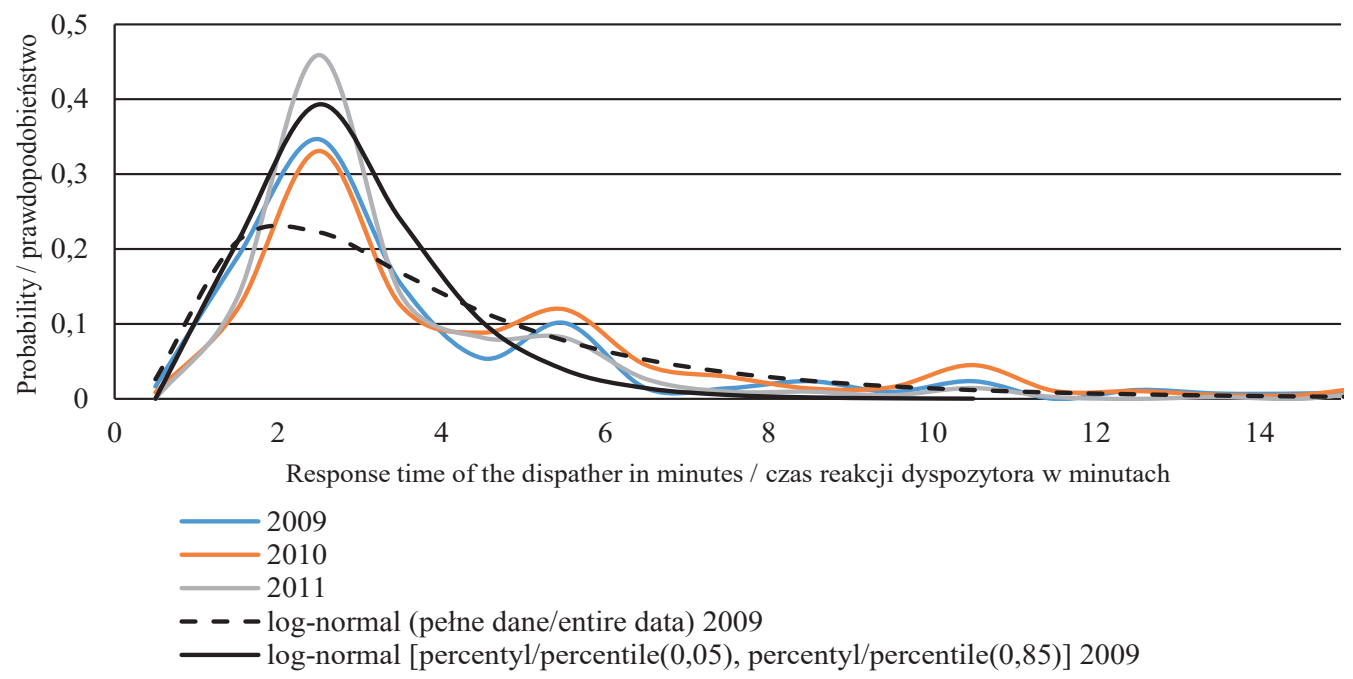

Figure 2. Histograms of distributions for dispatcher response timesin the years 2009-2011 and log-normal distributions approximating the distribution of 2009

Rycina 2. Histogramy rozkładów czasu reakcji dyspozytora w latach 2009-2011 oraz rozkładów logarytmicznie normalnych aproksymujących rozkład z roku 2009

Source: Own elaboration based on data from the SWD-ST 2.5 database.

Źródło: Opracowanie własne na podstawie danych z bazy SWD-ST 2,5.

Time taken by the rescue team to prepare for departure and to cover $7 \mathrm{~km}$

The SWD-ST 2.5 data basecontains data only on the time taken to dispatch the rescue team and to arrive at the scene. Such a database design renders it impossible to obtain, directly from the database, empirical distributions describing the time taken by rescuers to depart and to cover $1 \mathrm{~km}$ (the inverse of the travel technical speed). Hence, they should be isolated from the distribution describing the time from rescue team dispatch to arrival at the scene.

\footnotetext{
${ }^{6}$ This conclusion results from research also carried out as part of the same project.
}

Czas przygotowania do wyjazdu i pokonania 1 km przez zespół ratowniczy

W bazie danych SWD-ST 2,5 podawany jest jedynie czas zadysponowania zespołu ratowniczego oraz czas dotarcia tego zespołu do miejsca zdarzenia. Taka konstrukcja bazy danych wyklucza pozyskanie bezpośrednio z niej rozkładów empirycznych opisujących czas przygotowania ratowników do wyjazdu i czas przejazdu 1 km (odwrotność prędkości technicznej przejazdu). Należy je zatem wydzielić z rozkładu opisującego czas upływający od zadysponowania zespołu do jego dotarcia na miejsce zdarzenia.

\footnotetext{
${ }^{6}$ Wniosek ten wynika z badań prowadzonych również w ramach tego samego projektu.
} 
2006 rok / year

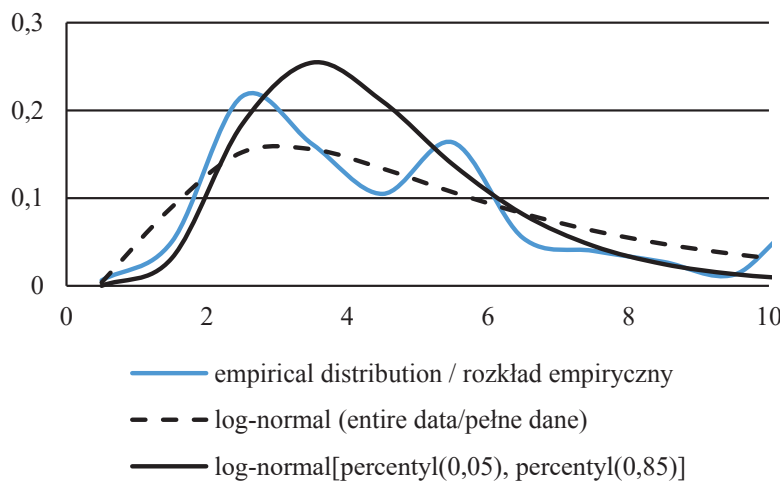

2010 rok / year

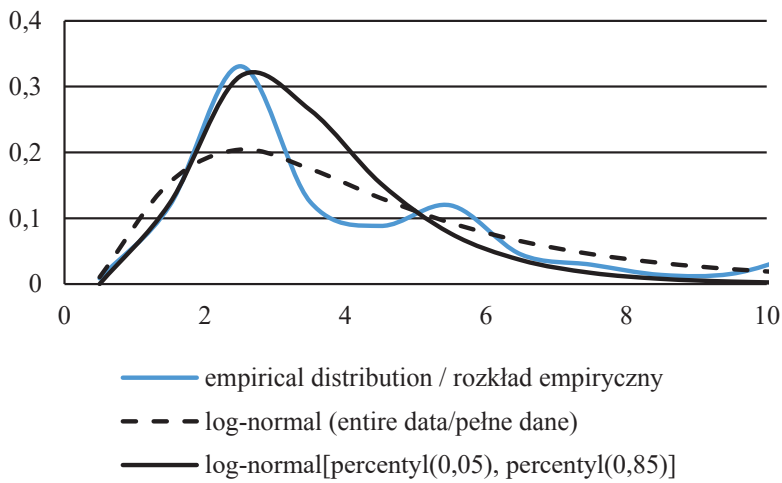

2007 rok / year

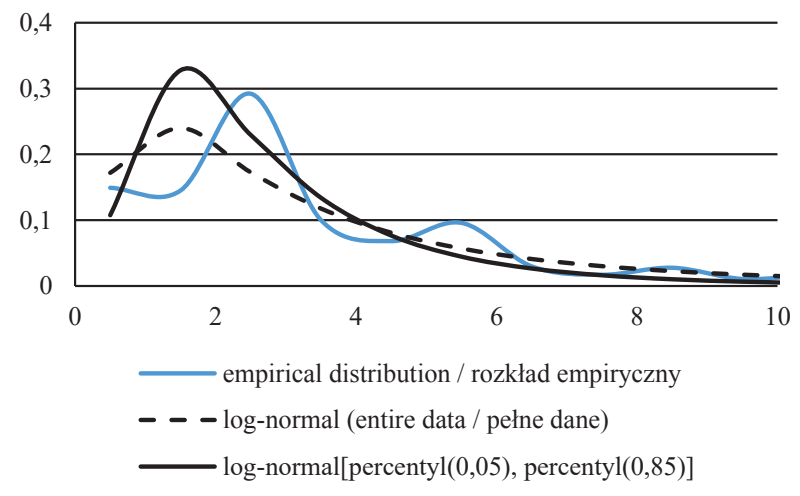

2011 rok / year

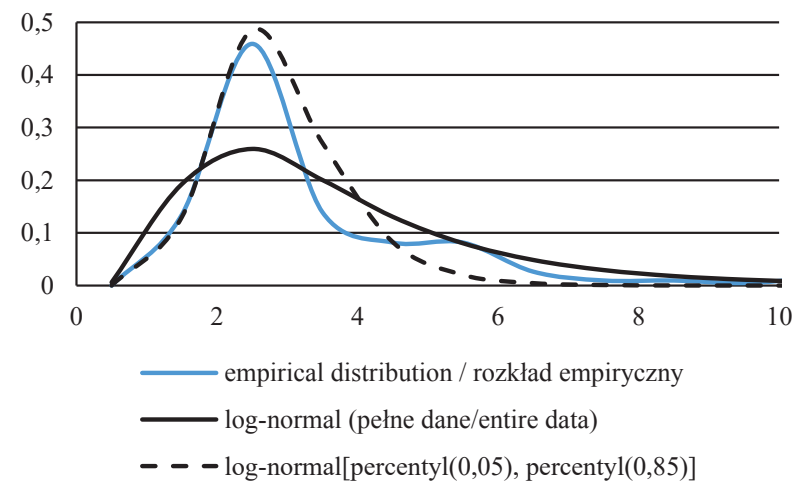

Figure 3. Comparison of histograms of empirical distributions for dispatcher response times with approximating log-normal distributions in respective years

Rycina 3. Porównanie histogramów empirycznych rozkładów czasu reakcji dyspozytora z aproksymującymi je rozkładami logarytmicznie normalnymi w poszczególnych latach

Source: Authors' work based on data from the SWD-ST 2.5 database.

Źródło: Opracowanie własne na podstawie danych z bazy SWD-ST 2,5.

Table 3. Summary of basic data for empirical distributions $Y=\ln (t A B)$ (Natural logarithms of dispatcher response times)

Tabela 3. Zestawienie podstawowych danych rozkładów empirycznych $Y=\ln (\mathrm{tAB})$ (logarytmów naturalnych czasu reakcji dyspozytora)

\begin{tabular}{|c|c|c|c|c|c|c|}
\hline & 2006 & 2007 & 2008 & 2009 & 2010 & 2011 \\
\hline & \multicolumn{6}{|c|}{ All empirical data / Wszystkie dane empiryczne } \\
\hline Average / Średnia & 1.55 & 0.96 & 1.04 & 1.16 & 1.31 & 1.16 \\
\hline Median / Mediana & 1.50 & 0.92 & 0.92 & 0.92 & 1.25 & 0.92 \\
\hline Mode / Dominanta & 0.92 & 0.92 & 0.92 & 0.92 & 0.92 & 0.92 \\
\hline Standard deviation / Odchylenie standardowe & 0.66 & 0.92 & 0.92 & 0.67 & 0.65 & 0.56 \\
\hline Sample variance / Wariancja próbki & 0.44 & 0.85 & 0.84 & 0.45 & 0.42 & 0.31 \\
\hline Kurtosis / Kurtoza & 0.32 & -0.08 & -0.13 & 0.82 & 0.12 & 2.21 \\
\hline Skewness / Skośność & 0.22 & -0.18 & -0.10 & 0.50 & 0.29 & 1.28 \\
\hline Number of data / Liczba danych & 477 & 469 & 481 & 424 & 577 & 416 \\
\hline
\end{tabular}


Empirical data from the interval $[(0.05)-(0.85)$ percentile] / Dane empiryczne z przedziału [percentyl $(0,05)-$ percentyl $(0,85)]$

\begin{tabular}{|c|c|c|c|c|c|c|}
\hline Average / Średnia & 1.42 & 0.80 & 0.87 & 1.01 & 1.17 & 1.01 \\
\hline Median / Mediana & 1.50 & 0.92 & 0.92 & 0.92 & 0.92 & 0.92 \\
\hline Mode / Dominanta & 0.92 & 0.92 & 0.92 & 0.92 & 0.92 & 0.92 \\
\hline Standard deviation / Odchylenie standardowe & 0.41 & 0.69 & 0.64 & 0.39 & 0.42 & 0.31 \\
\hline Sample variance / Wariancja próbki & 0.17 & 0.47 & 0.41 & 0.16 & 0.18 & 0.10 \\
\hline Kurtosis / Kurtoza & -0.88 & 0.32 & 0.65 & -0.67 & -0.80 & 0.14 \\
\hline Skewness / Skośność & 0.12 & -0.95 & -0.85 & 0.08 & 0.05 & 0.11 \\
\hline Number of data / Liczba danych & 379 & 371 & 381 & 337 & 461 & 331 \\
\hline
\end{tabular}

Source: Own elaboration based on data from the SWD-ST 2.5 database. Źródło: Opracowanie własne na podstawie danych z bazy SWD-ST 2,5.

To estimate the distribution describing the travel speed, it also essential to know the distance from the headquarters of the rescue team to the scene. Two values are recorded in the database: the coordinates of the scene and the number of kilometres covered by the rescue team. These values do not correspond with each other. Therefore, the actual distance was estimated using the coordinates of the scene and a Google Maps functionality that allows to read road distances based on geographical coordinates.

A particular problem is to isolate, from the variable describing the time from rescue team dispatch to arrival at the scene $\left(t_{B D}\right)$, the variables that describe the time taken by the team to prepare for departure $\left(t_{B C}\right)$ and the travel time $\left(t_{C D}\right)$. To this end, it was necessary to assume that the variable and, by implication, the variable components were normally distributed.

Suppose that:

$-T_{i} \sim N\left(\mu_{i}, \sigma_{i}^{2}\right)$ is a random variable describing time $t_{B D}$ for an event that is at a distance of $i-\mathrm{km}$ from the headquarters of the rescue teams;

$-T_{P} \sim N\left(\mu_{P}, \sigma_{P}^{2}\right)$ is a random variable describing time $t_{B C}$

$-T_{J} \sim N\left(\mu_{J}, \sigma_{J}^{2}\right)$ is a random variable describing the time taken bythe rescue team to cover $1 \mathrm{~km}$;

- $i=1,2,3, \ldots, n$ - distance of the event from the headquarters of the rescue teams (in kilometres);

Then:

$$
T_{i}=T_{P}+i T_{j} \sim N\left(\mu_{P}+i \mu_{J}, \sigma_{P}^{2}+i \sigma_{j}^{2}\right)
$$

Hence:

$$
T_{i+1}-T_{i}=T_{J}
$$

Since each of the variables on the left side of the equation (12) is a linear combination of the same two variables, one of which is the right side of the equation (12), the parameters that
Do oszacowania rozkładu opisującego prędkość przejazdu niezbędna jest również odległość miejsca zdarzenia od siedziby zespołów ratowniczych. W bazie danych zapisywane są dwie wielkości: współrzędne geograficzne miejsca zdarzenia oraz liczba pokonanych przez zespół ratowniczy kilometrów. Wielkości te nie korespondują ze sobą. Dlatego też rzeczywistą odległość szacowano, wykorzystując współrzędne geograficzne miejsca zdarzenia oraz funkcjonalność Map Google umożliwiającą odczytanie odległości wzdłuż dróg na podstawie współrzędnych geograficznych.

Szczególnym problemem jest wyodrębnienie ze zmiennej opisującej czas upływający od zadysponowania zespołu ratowniczego do jego dotarcia na miejsce zdarzenia $\left(t_{B D}\right)$, zmiennych opisujących: czas przygotowania zespołu do wyjazdu $\left(t_{B C}\right)$ oraz czas przejazdu $\left(t_{C D}\right)$. Dokonanie tego wymagało przyjęcia założenia o normalności rozkładu zmiennej, co implikuje przyjęcia założenia o normalności rozkładów zmiennych składowych.

Niech:

- $T_{i} \sim N\left(\mu_{i}, \sigma_{i}^{2}\right)$ oznacza zmienną losową opisującą czas $t_{B D}$ dla zdarzenia odległego od siedziby zespołów ratowniczych o $i-\mathrm{km}$;

- $T_{P} \sim N\left(\mu_{P}, \sigma_{P}^{2}\right)$ oznacza zmienną losową opisująca czas $t_{B C}$;

- $T_{J} \sim N\left(\mu_{J}, \sigma_{J}^{2}\right)$ oznacza zmienną losową opisującą czas pokonania przez zespół ratowniczy $1 \mathrm{~km}$;

$-i=1,2,3, \ldots, n$ to odległość zdarzenia od siedziby zespołów ratowniczych wyrażona w kilometrach;

Wówczas:

$$
T_{i}=T_{P}+i T_{j} \sim N\left(\mu_{P}+i \mu_{J}, \sigma_{P}^{2}+i \sigma_{j}^{2}\right)
$$

Stąd:

$$
T_{i+1}-T_{i}=T_{J}
$$

Ponieważ każda ze zmiennych po lewej stronie równania (12) jest kombinacją liniową dwóch tych samych zmiennych, z których jedna stanowi prawą stronę równania (12), oszaco- 
explicitly describe the variables $\left(\mu_{J}\right.$ and $\left.\sigma_{J}^{2}\right)$ must be estimatedby solving two algebraic equations, without taking into account the properties of the linear combination of normal distributions.

However, there is another explanation for this. If a random variable is a linear combination of two independent random variables, its variance (volatility) is also a linear combination of the variance of the same variables. When isolating one of the variables, we cannot duplicate its variance, as this as already been included in the common random variable.

Taking into account the above:

$$
\begin{aligned}
& \mu_{J i}=\mu_{i+1}-\mu_{i} \\
& \sigma_{J i}^{2}=\sigma_{i+1}^{2}-\sigma_{i}^{2}
\end{aligned}
$$

By isolating categories of events from empirical data according to event distance from the headquarters of the rescue team, we obtain the following sets of events: up to $1 \mathrm{~km}$, marked as $0 \mathrm{~km} ; 1-2 \mathrm{~km}$, marked as $1 \mathrm{~km} ; 2-3 \mathrm{~km}$, marked as $2 \mathrm{~km}$, etc. Each one is considered as reflecting the linear combination of two random variables (formula 11): the time taken by the rescue team to prepare for departure and to arrive at the scene. Next, they are approximated using normal distributions, with the mean valued termined as the estimator of the expected value, and the square of the standard deviation as the estimator of variance. This is followed by calculations according to formulas (13) and (14) for each of the distinguished sets of events. The result is a set of means and variances, in which there areas many elements as categories. If the categories were determined according to the previously formulated rule, then:

$$
\begin{gathered}
\mu_{J}=\frac{\sum_{i=1}^{n} \mu_{J i}}{n} \\
\sigma_{J}^{2}=\left|\frac{\sum_{i=1}^{n} \sigma_{k i}^{2}}{n}\right|
\end{gathered}
$$

Following the same logic, and knowing the distribution parameters describing the time taken to cover $1 \mathrm{~km}$, we determine the parameters of the random variable describing the time taken by the rescue team to prepare for departure.

$$
\begin{gathered}
\mu_{p i}=\mu_{i}-i \mu_{J} \\
\sigma_{p i}^{2}=\sigma_{i}^{2}-i \sigma_{J}^{2} \\
\mu_{p}=\frac{\sum_{i=1}^{n} \mu_{p i}}{n} \\
\sigma_{p}^{2}=\left|\frac{\sum_{i=1}^{n} \sigma_{p i}^{2}}{n}\right|
\end{gathered}
$$

Due scarcity of data from individual years for each category, the approximation was based on data from the years 2007-2009. Erroneous data, suggesting impossible travel speeds, was removed from the distinguished categories. It is hard to imagine a rescue team travelling in a high-priority vehicle at an average wania parametrów jednoznacznie ją opisujących $\left(\mu_{J}\right.$ oraz $\left.\sigma_{J}^{2}\right)$ należy dokonać poprzez rozwiązanie dwóch równań algebraicznych, bez uwzględniania własności kombinacji liniowej rozkładów normalnych.

Istnieje także inne wytłumaczenie. Jeżeli zmienna losowa jest kombinacją liniową dwóch niezależnych zmiennych losowych, to jej wariancja (zmienność) jest również kombinacją liniową wariancji tych samych zmiennych. Wyodrębniając jedną ze zmiennych składowych, nie możemy powielać jej wariancji, która już została uwzględniona we wspólnej zmiennej losowej.

Biorąc pod uwagę powyższe:

$$
\begin{aligned}
& \mu_{J i}=\mu_{i+1}-\mu_{i} \\
& \sigma_{J i}^{2}=\sigma_{i+1}^{2}-\sigma_{i}^{2}
\end{aligned}
$$

Wyodrębniając z danych empirycznych kategorie zdarzeń ze względu na ich odległość od siedziby zespołu ratowniczego, otrzymujemy zbiory zdarzeń: do $1 \mathrm{~km}$ oznaczając ją jako $0 \mathrm{~km}$; od 1-2 km oznaczając ją jako $1 \mathrm{~km}$; od 2-3 km oznaczając ją jako 2 km, itd. Każdy z nich traktujemy jako realizację kombinacji liniowej dwóch zmiennych losowych (wzór 11): czasu przygotowania do wyjazdu i czasu przejazdu zespołu ratowniczego do miejsca zdarzenia. Aproksymujemy je rozkładami normalnymi, wyznaczając wartość średnią jako estymator wartości oczekiwanej oraz kwadrat odchylenia standardowego, jako estymator wariancji. Następnie dokonujemy obliczeń zgodnie ze wzorami (13) i (14) dla każdego z wyróżnionych zbiorów zdarzeń. Ich efektem jest zbiór średnich i wariancji zawierający tyle elementów, ile wyróżniliśmy kategorii. Jeżeli kategorie ustalone zostały zgodnie z wcześniej sformułowaną regułą, wówczas:

$$
\begin{gathered}
\mu_{J}=\frac{\sum_{i=1}^{n} \mu_{J i}}{n} \\
\sigma_{J}^{2}=\left|\frac{\sum_{i=1}^{n} \sigma_{k i}^{2}}{n}\right|
\end{gathered}
$$

Stosując ten sam schemat rozumowania oraz znając parametry rozkładu opisującego czas przejazdu $1 \mathrm{~km}$, wyznaczamy parametry zmiennej losowej opisującej czas przygotowania zespołu ratowniczego do wyjazdu.

$$
\begin{gathered}
\mu_{p i}=\mu_{i}-i \mu_{J} \\
\sigma_{p i}^{2}=\sigma_{i}^{2}-i \sigma_{J}^{2} \\
\mu_{p}=\frac{\sum_{i=1}^{n} \mu_{p i}}{n} \\
\sigma_{p}^{2}=\left|\frac{\sum_{i=1}^{n} \sigma_{p i}^{2}}{n}\right|
\end{gathered}
$$

Ze względu na niewielką ilość danych z pojedynczych lat dla każdej kategorii, aproksymacji dokonano $w$ oparciu o dane $z$ lat 2007-2009. W wyodrębnionych kategoriach usunięto błędne dane wskazujące niemożliwe do osiągnięcia średnie prędkości przejazdu. Trudno wyobrazić sobie, aby zespół ratowniczy poru- 
speed of over $70 \mathrm{~km} / \mathrm{h}$ or under $30 \mathrm{~km} / \mathrm{h}$. Such vehicles run on normal roads with intersections.

After categorising and cleaning data, according to the adopted rules mentioned above, we tested the normality of the distribution which describes the time from rescue team dispatch to arrival at the scene for each category using the Kormołogow-Smirnov test (the results are summarised in table 4). The critical value of this test for a significance of 0.05 is 1.358 . Thus, if the test result is less than the critical value, then there is no reason to reject the hypothesis that the distributions tested are normally distributed. szający się pojazdem uprzywilejowanym osiągnął średnią prędkość przejazdu powyżej $70 \mathrm{~km} / \mathrm{h}$ lub poniżej $30 \mathrm{~km} / \mathrm{h}$. Porusza się on po normalnych drogach ze skrzyżowaniami.

Po kategoryzacji danych i ich oczyszczeniu, zgodnie z przyjętymi powyżej regułami, dokonano sprawdzenia normalności rozkładu opisującego czas upływający od zadysponowania zespołu do jego dotarcia na miejsce zdarzenia, dla każdej kategorii, dla każdej kategorii wykorzystując test Kormołogowa-Smirnowa (wyniki zestawiono w tabeli 4). Wartość krytyczna tego testu dla poziomu istotności 0,05 wynosi 1,358. Jeżeli zatem wynik testu jest mniejszy od wartości krytycznej, to nie ma podstaw do odrzucenia hipotezy o normalności badanych rozkładów.

Table 4. Results of the Kolmogorow-Smirnow test for each category of data

Tabela 4. Wyniki testu Kołmogorowa-Smirnowa dla poszczególnych kategorii danych

\begin{tabular}{cccccccc}
\hline Category / kategoria & $\mathbf{3}$ & $\mathbf{4}$ & $\mathbf{5}$ & $\mathbf{6}$ & $\mathbf{7}$ & $\mathbf{8}$ \\
\hline Distance / odległość & {$[3-4) \mathrm{km}$} & {$[4-5) \mathrm{km}$} & {$[5-6) \mathrm{km}$} & {$[6-7) \mathrm{km}$} & {$[7-8) \mathrm{km}$} & {$[8-9) \mathrm{km}$} & {$[9-10) \mathrm{km}$} \\
\hline Test value / Wartość testu & 1.16 & 0.804 & 1.034 & 1.101 & 1.419 & 0.957 \\
\hline
\end{tabular}

Source: Own elaboration based on data from the SWD-ST 2.5 database for the years 2007-2009.

Źródło: Opracowanie własne na podstawie danych z bazy SWD-ST 2,5 z lat 2007-2009.

The above data validate the hypothesis that the distribution describing the time taken from rescue team dispatch to arrival at the scene is normal.

When examining the normality of the distribution of this random variable, we also estimated the basic parameters of empirical distributions for each category of event. Some of this data is presented in table 5 (complete calculations were based on categories from 1 to 12). Based on this data, using the above formulas, we estimated the parameters of distributions describing time $t_{p}$ and $t_{j}$ :

$$
\begin{aligned}
t_{J} & \sim N(1,23 ; 1,046) \\
t_{P} & \sim N(4,97 ; 0,549)
\end{aligned}
$$

$4 \mathrm{~km}$ category / kategoria $4 \mathrm{~km}$

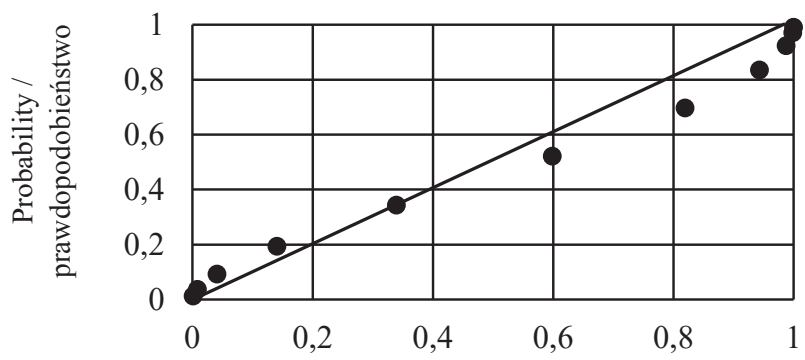

Probability / prawdopodobieństwo
Jak wynika z powyższych danych, hipotezę o normalności rozkładu opisującego czas upływający od zadysponowania zespołu do jego dotarcia na miejsce zdarzenia należy uznać za prawdziwą.

Badając normalność rozkładu tej zmiennej losowej, oszacowano również podstawowe parametry rozkładów empirycznych dla poszczególnych kategorii zdarzeń. Fragment tych danych przedstawiono $w$ tabeli 5 (pełne obliczenia oparto na kategoriach od 1 do 12). Na ich podstawie oszacowano, zgodnie z powyższymi wzorami, parametry rozkładów opisujących czas $t_{p}$ oraz $t_{j}$ :

$$
\begin{aligned}
t_{J} & \sim N(1,23 ; 1,046) \\
t_{P} & \sim N(4,97 ; 0,549)
\end{aligned}
$$

$8 \mathrm{~km}$ kategory / kategoria $8 \mathrm{~km}$

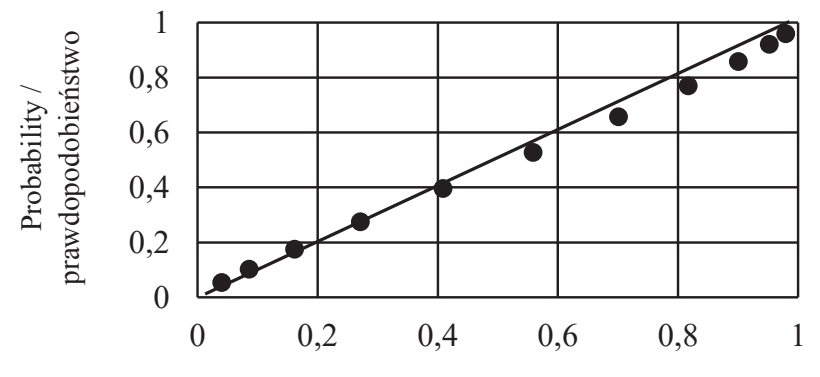

Probability / prawdopodobieństwo

Figure 4. Charts of the distribution function expressed by formula (11) as a distribution function approximating the empirical distribution Rycina 4. Wykresy dystrybuanty rozkładu opisanego wzorem [11] w funkcji dystrybuanty rozkładu aproksymującego rozkład empiryczny Source: Own elaboration based on data from the SWD-ST 2.5 database for the years 2007-2009.

Źródło: Opracowanie własne na podstawie danych z bazy SWD-ST 2,5 z lat 2007-2009. 
After isolating the variables, we tested the compatibility of the distributions, determining their parameters from empirical data and by using the linear combination of the distributions describing the time taken to cover one kilometre, and to prepare for departure $\left(t=t_{P}+i \cdot t_{J}\right)$. For compatibility analysis, we used probability - probability (P-P) charts, which are partly presented in figure 4 . Our analysis showed that the procedure used to isolate random variables was correct.

Figure 5 shows the incidence of specific values of a random variable describing the time from rescue team dispatch to arrival at the scene based on: actual data, approximation using normal distribution (data from table 5) and simulation using estimated parameters of the random-variable components (time taken to prepare for departure and cover $1 \mathrm{~km}$ ). Histograms are again presented as continuous distributions, although in fact they are discrete distributions with an interval length of $1 \mathrm{~min}$.

$5 \mathrm{~km}$ distance / odległość $5 \mathrm{~km}$
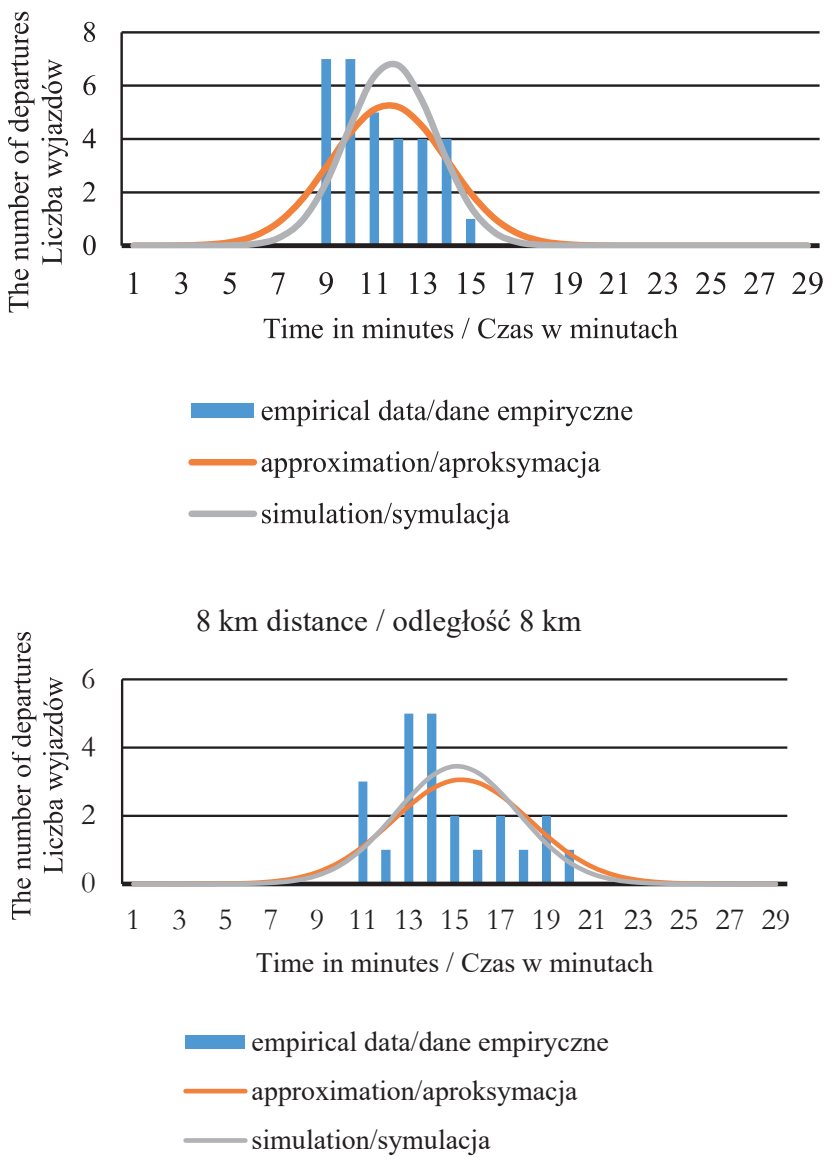

Po wyodrębnieniu zmiennych dokonano sprawdzenia zgodności rozkładów, których parametry wyznaczono z danych empirycznych oraz z wykorzystaniem liniowej kombinacji rozkładów opisujących czas pokonania jednego kilometra i przygotowania do wyjazdu $\left(t=t_{P}+i \cdot t_{J}\right)$. Do analizy zgodności wykorzystano wykresy prawdopodobieństwo - prawdopodobieństwo $(P-P)$, których część zaprezentowano na rycinie 4. Dokonane analizy wskazują na poprawność przyjętej procedury wyodrębniania zmiennych losowych.

Na rycinie 5 przedstawiono częstość występowania danej wartości zmiennej losowej opisującej czas upływający od zadysponowania zespołu do jego dotarcia na miejsce zdarzenia na podstawie danych: rzeczywistych, aproksymacji rozkładem normalnym (dane z tabeli 5) oraz symulacji wykorzystującej oszacowane parametry składowych zmiennych losowych (czasu przygotowania do wyjazdu oraz czasu przejazdu na odległość 1 $\mathrm{km}$ ). Histogramy zaprezentowano $w$ dotychczasowej konwencji rozkładów ciągłych, choć w rzeczywistości są to rozkłady dyskretne o długości przedziału 1 min.

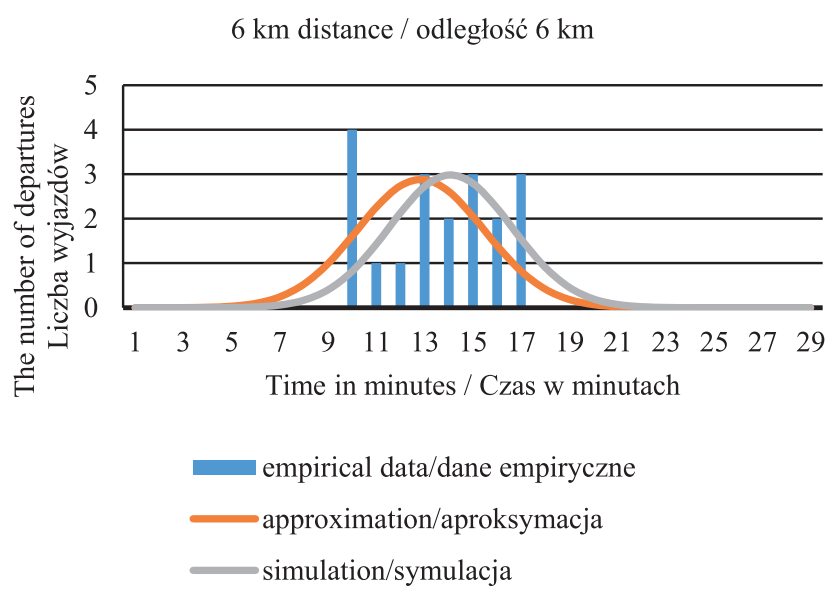

$10 \mathrm{~km}$ distance / odległość $10 \mathrm{~km}$

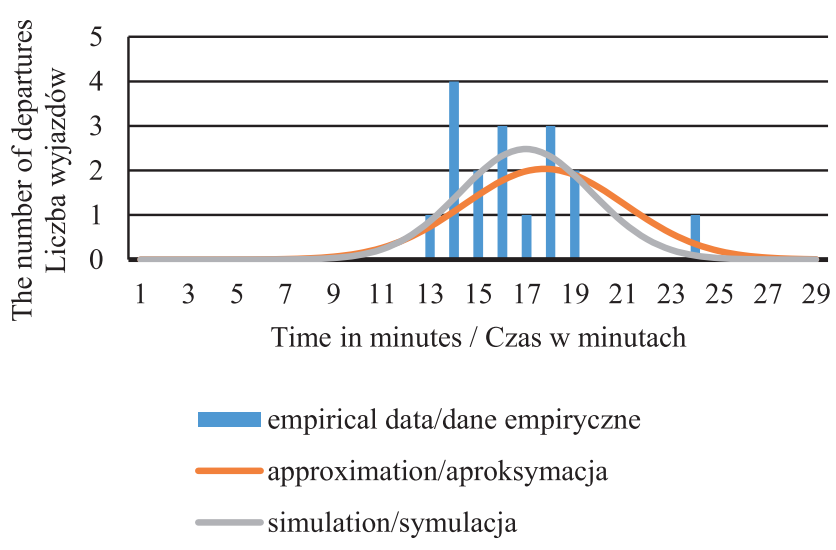

Figure 5. Histogram of the time from rescue team dispatch to arrival at the sceneat different distances based on empirical data and approximation using normal distribution and simulation

Rycina 5. Histogram rozkładu czasu upływającego od zadysponowania zespołu do jego dotarcia na miejsce zdarzenia dla różnych odległości na podstawie danych: empirycznych, aproksymacji rozkładem normalnym oraz symulacji

Source: Own elaboration based on data from the SWD-ST 2.5 database.

Źródło: Opracowanie własne na podstawie danych z bazy SWD-ST 2,5. 
A comparative analysis of simulation, approximation and empirical data (some of which are presented in figure 5) indicates a significant compliance between histograms based on simulations and approximations. This largely confirms the validity of the variable-separation method presented above (see also figure 4). However, the comparison of histograms of empirical distributions with approximation and simulation-based distributions indicates a certain discrepancy. This is due to the fact that the shape of the approximating distribution was assumed beforehand. This assumption also led to the separation of variables, resulting in their normal distribution.

Assuming that the dominant component in the $0 \mathrm{~km}$ category, including distances of less than $1 \mathrm{~km}$ from the headquarters of the rescue teams, is the variable describing the time taken by the rescue team to depart, we approximated the empirical distribution using normal and log-normal distributions. As a result, we found that the preparation time of the rescue team was described using the log-normal distribution. This is indicated by a chi-squared test at a significance level of 0.01 . However, such a distribution prevents the isolation of the other variable - the time taken by the rescue team to cover $1 \mathrm{~km}$. Therefore, in the future, the database should additionally record the times taken by the rescue teams to leave the station once they are dispatched.

\section{Approximation of rescue operation times}

Rescue operation times (cf. [4]) depend largely on the magnitude of the event. This magnitude can be determined by two main parameters: rescue operation time and the number of rescue teams involved in the operations. Figure 6 presents the empirical distribution of rescue operation times in 2008 in the form of box plots. Operations with 1 rescue team accounted for $54 \%$ of all events, 2 rescue teams $-30 \%, 3$ rescue teams $-9 \%$, more than 3 rescue teams $-8 \%$.
Analiza porównawcza symulacji, aproksymacji i danych empirycznych (fragment zaprezentowano na rycinie 5) wskazuje na znaczną zgodność histogramów opartych na symulacji oraz aproksymacji, co w znacznym stopniu potwierdza słuszność zaprezentowanej powyżej metody rozdzielenia zmiennych (zob. również rycina 4). Porównanie natomiast histogramów rozkładów empirycznych z aproksymacją i symulacją wskazuje na pewną ich rozbieżność. Wynika to z faktu, iż założono kształt rozkładu aproksymującego. Stanowił on również podstawę do rozdzielenia zmiennych, które w związku z tym również zachowały rozkład normalny.

Przyjmując założenie, że dominującą składową w kategorii $0 \mathrm{~km}$, obejmującej wyjazdy na odległość mniejszą niż $1 \mathrm{~km}$ od siedziby zespołów ratowniczych, jest zmienna opisująca czas przygotowania zespołu do wyjazdu, dokonano aproksymacji rozkładu empirycznego rozkładami: normalnym i logarytmicznie normalnym. W jej wyniku okazało się, że czas przygotowania zespołu ratowniczego opisany jest rozkładem logarytmicznie normalnym. Wskazuje na to test chi-kwadrat na poziomie istotności 0,01 . Jednakże przyjęcie takiego rozkładu uniemożliwia wyodrębnienie drugiej zmiennej - czasu pokonania $1 \mathrm{~km}$ przez zespół ratowniczy. Dlatego też w przyszłości należałoby umieszczać $w$ bazie danych dodatkowo czas wyjazdu zespołu ratowniczego po otrzymaniu dyspozycji.

\section{Aproksymacja czasu trwania działań ratowniczych}

Czas trwania działań ratowniczych (por. [4]) zależy w dużym stopniu od wielkości tych zdarzeń, którą można określić za pomocą dwóch podstawowych parametrów: czasu trwania działań ratowniczych oraz liczby zaangażowanych $w$ te działania zespołów ratowniczych. Na rycinie 6 zaprezentowano empiryczny rozkład czasu trwania działań ratowniczych w roku 2008 w postaci wykresów pudełkowych. Działania, w których brało udział: 1 zespół ratowniczych stanowiły $54 \%$ wszystkich akcji, 2 zespoły ratownicze $-30 \%$, 3 zespoły ratownicze $-9 \%$, więcej niż 3 zespoły ratownicze $-8 \%$.

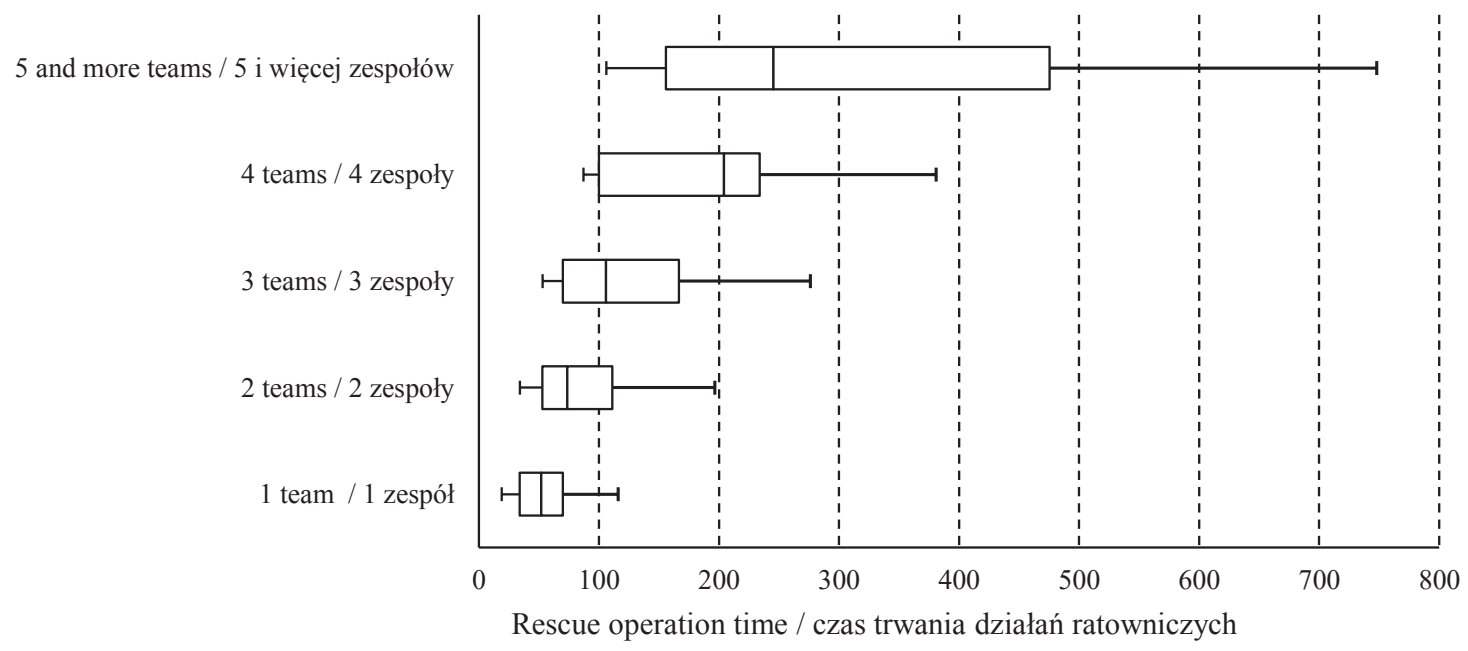

Figure6. Box plots of rescue operation times by number of rescue teams involved (2008)

Rycina 6. Wykresy pudełkowe czasu trwania działań ratowniczych w zależności od liczby zaangażowanych zespołów ratowniczych w 2008 roku Source: Own elaboration based on data from the SWD-ST 2.5 database.

Źródło: opracowanie własne na podstawie danych z bazy SWD-ST 2,5. 
As rescue operations conducted by at least 3 rescue teams accounted for $92 \%$ of all events, we studied further only those events. Figure 6 shows that the rescue operation times can be described by a log-normal distribution. Hence, table 6 contains the basic data on the natural-logarithm distribution of rescue operation times, with Kolmogorov-Smirnov test (KS-test) statistics for 11 intervals. The critical value of this test for a significance level of 0.05 is 1.358 . It is, therefore, concluded that rescue operation times are described using a log-normal distribution.

The chi-square tests on the consistency of empirical distributions for rescue operation times in individual categories, with theoretical distributions of the natural logarithm of these times (distribution parameters in table 5), did not warrant the rejection of the hypothesis that they were consistent. When comparing rescue operation times in respective years with the log-normal distribution of these times in 2008, the chi-square test indicated a growing discrepancy over the years. For 2011 the test did not confirm the consistency of these distributions.

However, the tests show that the distribution of the rescue operation times can be approximated by a log-normal distribution with the parameters estimated using data from past 2-3 years. Thus, based on data from the current year, we can predict the distribution of the rescue operation times in the coming years, as in the case of other components of emergency response times discussed earlier.
Ponieważ działania ratownicze prowadzone przez co najmniej 3 zespoły ratownicze stanowią 92\% wszystkich zdarzeń, dalszym badaniom poddano jedynie te zdarzenia. Rycina 6 wskazuje, że czas trwania działań ratowniczych można opisać rozkładem logarytmicznie normalnym. Dlatego też w tabeli 6 zamieszczono podstawowe dane rozkładów logarytmu naturalnego czasu trwania działań ratowniczych wraz z wartością statystyki testu Kołmogorowa-Smirnowa dla 11 przedziałów. Wartość krytyczna tego testu dla poziomu istotności 0,05 wynosi 1,358. Należy zatem stwierdzić, że czas trwania działań ratowniczych opisany jest rozkładem logarytmicznie normalnym.

Przeprowadzone testy chi-kwadrat zgodności rozkładów empirycznych czasu trwania działań ratowniczych w poszczególnych kategoriach z teoretycznymi rozkładami logarytmu naturalnego tego czasu (parametry rozkładu w tabeli 5.) nie upoważniają do odrzucenia hipotezy o ich zgodności. Porównując natomiast czas działań ratowniczych w kolejnych latach z rozkładem logarytmicznie normalnym tego czasu z roku 2008 , test chi-kwadrat wskazuje na rosnącą z upływem lat rozbieżność. Dla roku 2011 wspomniany test nie potwierdza już zgodności tych rozkładów.

Niemniej jednak przeprowadzone testy wskazują, że rozkład czasu trwania działań ratowniczych można aproksymować rozkładem logarytmicznie normalnym o parametrach oszacowanych na podstawie danych sprzed 2-3 lat. Oznacza to, że na podstawie danych z roku bieżącego możemy przewidzieć rozkład czasu trwania działań ratowniczych w latach najbliższych, podobnie jak to miało miejsce w przypadku, zaprezentowanych powyżej, pozostałych składowych czasu reakcji służb ratowniczych.

Table 6. Descriptive statistics of empirical distributions for the natural-logarithm of rescue operation times in 2008 with the Kolmogorov-Smirnov test statistics

Tabela 6. Statystyka opisowa empirycznych rozkładów logarytmu naturalnego czasu trwania działań ratowniczych w 2008 roku wraz ze statystyką testu Kołmogorowa-Smirnowa

\begin{tabular}{|c|c|c|c|}
\hline & $\begin{array}{c}1 \text { rescue team } \\
1 \text { zespół ratowniczy }\end{array}$ & $\begin{array}{c}2 \text { rescue teams } \\
2 \text { zespoły ratownicze }\end{array}$ & $\begin{array}{c}3 \text { rescue teams } \\
3 \text { zespoły ratownicze }\end{array}$ \\
\hline Average / Średnia & 3.89 & 4.33 & 4.69 \\
\hline Median / Mediana & 3.95 & 4.30 & 4.66 \\
\hline Mode / Dominanta & 3.56 & 3.89 & 4.25 \\
\hline Standard deviation / Odchylenie standardowe & 0.54 & 0.42 & 0.53 \\
\hline Sample variance / Wariancja próbki & 0.30 & 0.18 & 0.28 \\
\hline Kurtosis / Kurtoza & -0.41 & -0.74 & -0.84 \\
\hline Skewness / Skośność & -0.15 & 0.23 & 0.29 \\
\hline Minimum & 2.56 & 3.56 & 3.87 \\
\hline Maximum / Maksimum & 5.15 & 5.27 & 5.77 \\
\hline Number of events / Liczba zdarzeń & 259 & 128 & 42 \\
\hline K-S test statistics / Statystyka testu K-S & 1.256 & 0.977 & 0.821 \\
\hline
\end{tabular}

Source: Own elaboration based on data from the SWD-ST 2.5 database.

Źródło: Opracowanie własne na podstawie danych z bazy SWD-ST 2,5. 


\section{Model test}

Model tests were carried out by comparing the results obtained by simulation based on data from 2009, and in the case of variables $t_{B C}$ and $t_{C D}$ - based on data from the years 2007-2009, with the empirical data from the years 2010 and 2011. In order to carry out full simulations, it is necessary to describe the process that generates the spatial distribution of events, and this is beyond the scope of this article. Therefore, we focused only on determining the operational responsibility area of the rescue teams.

The size of this area is defined as the distance of event location from the headquarters of the rescue teams, ensuring, with a predefined probability (e.g.: 0.8), that the rescue teams arrive at the scene within a specific time. Let us assume that the time limit ensuring the effectiveness of the rescue operations is 20 minutes. For our simulation, we used a set of data presented in table 7 , where:

$t_{D}$ - dispatcherresponse time;

$t_{j}$ - time taken to cover $1 \mathrm{~km}$;

$t_{p}$-time taken bythe rescue team to prepare for departure.

Microsoft Office 2013 spreadsheet was used for the simulation. Five hundred executions were drawn from the variables presented in table 7. Executions of variable $t$, were drawn using the normal truncated distribution. The truncated lower limit was set at $30 \mathrm{~km} / \mathrm{h}$ (variable - $1.71 \mathrm{~min} / \mathrm{km}$ ), while the upper limit was set at $70 \mathrm{~km} / \mathrm{h}$ (variable $-1 \mathrm{~min} / \mathrm{km}$ ). It should be noted that the separation of variables $t_{J}$ and $t_{p}$ was based on the assumption that the distance of $8 \mathrm{~km}$ corresponds to the distance from the interval $[8,9]$. The results of the simulation together with empirical data from the years 2010 and 2011 are summarised in table 8 .

\section{Test modelu}

Testy modelu przeprowadzono porównując wyniki otrzymane w wyniku symulacji opartej na danych z roku 2009 (a w przypadku zmiennych $t_{B C}$ i $t_{C D}$ na podstawie danych z lat 2007-2009), z danymi empirycznymi z lat 2010 i 2011 . Do przeprowadzenia pełnych symulacji niezbędny jest opis procesu generującego przestrzenny rozkład zdarzeń, którego nie przedstawiono w niniejszym artykule. Dlatego też skupiono się jedynie na aspekcie określenia obszaru operacyjnej odpowiedzialności zespołów ratowniczych.

Wielkość tego obszaru definiujemy poprzez określenie odległości zdarzeń od siedziby zespołów ratowniczych zapewniającej, z zadanym prawdopodobieństwem (np.: 0,8), dotarcie zespołów ratowniczych do tych miejsc w zadanym czasie. Przyjmijmy, że czasem granicznym zapewniającym skuteczność działań ratowniczych jest 20 min. Do symulacji przyjęto zestaw danych ujętych w tabeli 7 , gdzie:

$t_{D}$ - czas reakcji dyspozytora;

$t_{\mathrm{J}}$ - czas pokonania $1 \mathrm{~km}$;

$t_{p}$ - czas przygotowania zespołu ratowniczego do wyjazdu.

Do przeprowadzenia symulacji zastosowano arkusz kalkulacyjny Microsoft Office 2013. Losowano 500 realizacji wskazanych w tabeli 8 zmiennych. Realizacje zmiennej $t$, losowano według uciętego rozkładu normalnego. Dolną granicę ucięcia przyjęto na poziomie $30 \mathrm{~km} / \mathrm{h}$ (wartość zmiennej - 1,71 min/km), górną zaś na poziomie $70 \mathrm{~km} / \mathrm{h}$ (wartość zmiennej - $1 \mathrm{~min} / \mathrm{km}$ ). Należy w tym miejscu przypomnieć, że rozdzielenia zmiennych $t_{J}$ i $t_{p}$ dokonano przy założeniu, że odległość $8 \mathrm{~km}$ odpowiada odległości z przedziału $[8,9])$. Wyniki symulacji wraz $z$ danymi empirycznymi z lat 2010 i 2011 zestawiono $w$ tabeli 8.

Table 7. Set of parameters of normal distributions used for the simulation Tabela 7. Zestaw parametrów rozkładów normalnych przyjętych do symulacji

\begin{tabular}{cccc}
\hline $\begin{array}{c}\text { Parameter } \\
\text { Parametr }\end{array}$ & Variable / Zmienna & t & tJ \\
\cline { 2 - 4 } & 1.01 & 1.23 & 4.97 \\
\hline $\begin{array}{c}\text { Expected value } \\
\text { Wartość oczekiwana }\end{array}$ & 0.39 & 1.023 & 0.741 \\
\hline $\begin{array}{c}\text { Standard deviation } \\
\text { Odchylenie standardowe }\end{array}$ & & & \\
\hline
\end{tabular}

Source: Summary of data from the article.

Źródło: Zestawienie danych z artykułu.

Looking at the simulations, it can be concluded that the boundaries of the operational responsibility area for the State Fire Brigade team under study should be at a distance of no more than $8 \mathrm{~km}$ from the headquarters. This guarantees that the rescue team will arrive to the responsibility area boundary in no more than 20 minutes from when the dispatcher receives the call in at least $80 \%$ of cases. As presented in table 8 , defining this distance based on empirical data can be difficult due to data scarcity. However, combining data from a large number of years is not recommended due to changes in traffic conditions
Z przeprowadzonych symulacji wynika, że granice obszaru operacyjnej odpowiedzialności dla badanej jednostki PSP powinny znajdować się w odległości nie większej niż 8 km od jej siedziby. Gwarantuje to dotarcie zespołów ratowniczych do granicy obszaru odpowiedzialności w czasie nie dłuższym niż 20 min od przyjęcia zgłoszenia przez dyspozytora, co najmniej w $80 \%$ przypadków. Jak wynika z tabeli 8, wyznaczenie tej odległości na podstawie danych empirycznych może nastręczać trudności ze względu na zbyt małą ilość danych. Z kolei łączenie danych z dużej liczby lat nie jest wskazane ze względu na zmiany warunków komunikacyj- 
(road improvements, alterations, new roads). Therefore, the proposed method of simulation can be very useful, especially to investigate the correctness of the distribution of individual teams.

In order to run more reliable simulations, the database should record the time taken by the rescue teams to prepare for departure. This way, the time taken to prepare for departure and to cover $1 \mathrm{~km}$ could described much more reliably using a lognormal distribution. Approximation using such distributions requires the availability of separate empirical data. nych (poprawę nawierzchni dróg, ich przebudowę, czy też powstanie nowych). Dlatego też zaproponowany sposób symulacji może być bardzo użyteczny, zwłaszcza jeżeli zastanawiamy się nad poprawnością rozmieszczenia poszczególnych jednostek.

Do prowadzenia bardziej rzetelnych symulacji należałoby zapisywać w bazie danych czas wyjazdu zespołu ratowniczego do zdarzenia. Wówczas czas przygotowania do wyjazdu oraz pokonania jednego kilometra można by opisać znacznie lepiej rozkładem logarytmicznie normalnym. Aproksymacja takimi rozkładami wymaga posiadania odrębnych danych empirycznych.

Table 8. The probability that the rescue team arrives at the scene in no more than 20 minutes - a comparison of simulation results and empirical data Tabela 8. Prawdopodobieństwo dotarcia zespołu ratowniczego na miejsce zdarzenia w czasie nie dłuższym niż 20 min - porównanie wyników symulacji oraz danych empirycznych

\begin{tabular}{|c|c|c|c|c|c|c|c|c|c|c|}
\hline \multirow{2}{*}{ 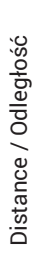 } & \multicolumn{3}{|c|}{$\begin{array}{c}\text { Empirical data from } 2010 \\
\text { Dane empiryczne z roku } 2010\end{array}$} & \multicolumn{3}{|c|}{$\begin{array}{c}\text { Empirical data from } 2011 \\
\text { Dane empiryczne z roku } 2011\end{array}$} & \multicolumn{3}{|c|}{$\begin{array}{c}\text { Empirical data from } 2010 \text { and } 2011 \\
\text { Dane empiryczne } z \text { lat } 2010-2011 \text { łącznie }\end{array}$} & \multirow{2}{*}{ 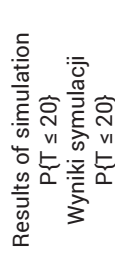 } \\
\hline & 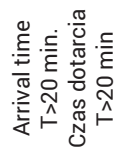 & 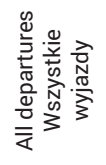 & $\begin{array}{l}\underset{\mathrm{D}}{\mathrm{v}} \\
\stackrel{5}{5}\end{array}$ & 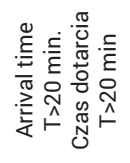 & 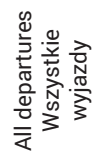 & $\begin{array}{l}\underset{\mathrm{O}}{\mathrm{v}} \\
\text { vi } \\
\stackrel{\leftarrow}{\sigma}\end{array}$ & 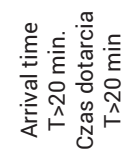 & 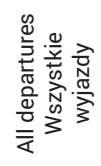 & $\begin{array}{l}\text { ণ } \\
\text { vi } \\
\text { to }\end{array}$ & \\
\hline 4 & 4 & 28 & 0.86 & 4 & 24 & 0.83 & 8 & 52 & 0.85 & 1.00 \\
\hline 5 & 2 & 15 & 0.87 & 1 & 8 & 0.88 & 3 & 23 & 0.87 & 1.00 \\
\hline 6 & 8 & 23 & 0.65 & 0 & 17 & 1.00 & 8 & 40 & 0.80 & 0.99 \\
\hline 7 & 5 & 32 & 0.84 & 1 & 11 & 0.91 & 6 & 43 & 0.86 & 0.96 \\
\hline 8 & 4 & 36 & 0.89 & 2 & 12 & 0.83 & 6 & 48 & 0.88 & 0.82 \\
\hline 9 & 9 & 19 & 0.53 & 1 & 5 & 0.80 & 10 & 24 & 0.58 & 0.63 \\
\hline 10 & 5 & 16 & 0.69 & 1 & 3 & 0.67 & 6 & 19 & 0.68 & 0.42 \\
\hline
\end{tabular}

Source: Own elaboration.

Źródło: Opracowanie własne.

\section{Conclusions}

The method of approximating the duration of individual emergency-response stages using theoretical distributions of random variables, as presented in this article, is largely consistent with the empirical data. It also allows to predict how the system will work in the short-term (over a time span of several years). The predictive property of such modelling can be used to optimise the deployment and to determine the capabilities of individual rescue teams. A model of spatial distribution of events requiring rescue operations should be additionally designed to fully utilise the potential of this model. Such a model has been designed as part of the same project. However, due to space constraints, this could not be presented in this article. This obviously made it impossible to present the full functionality of the emergency response model. It includes the following:

- determining operational responsibility areas of individual rescue teams;

\section{Zakończenie}

Wskazany w niniejszym artykule sposób aproksymacji czasu trwania poszczególnych etapów procesu reagowania służb ratowniczych, teoretycznymi rozkładami zmiennych losowych, jest $w$ znacznym stopniu zgodny $z$ danymi empirycznymi. Pozwala również na przewidywanie działania tego systemu w krótkiej (kilkuletniej) perspektywie czasowej. Własność predykcyjna takiego modelowania może być wykorzystana do optymalizacji rozmieszczenia i określenia potencjału poszczególnych jednostek ratowniczych. Do pełnego wykorzystania tego modelu należy jeszcze skonstruować model przestrzennego pojawiania się zdarzeń wymagających prowadzenia działań ratowniczych. Model taki został również skonstruowany w ramach tego samego projektu, jednakże ze względu na limity objętościowe artykułu nie mógł być zaprezentowany. To oczywiście możliwość zaprezentowania pełnej funkcjonalności modelu reagowania służb ratowniczych. Zaliczyć do niej możemy: 
- determining the stationing locations of individual rescue teams as necessitated by the spatial density of events requiring rescue operations;

- assessing readiness to act of individual teams and units(groups of teams);

- adjusting the capabilities of rescue teams to the number and type of events requiring response;

- assessing the availability of rescue teams - one of the elements determining their capabilities;

- $\quad$ supporting the decision-making processes of the emergency services.

It is very labour-intensive to do calculations (parameter estimation and selection of theoretical distributions) and simulations to solve the problem at hand using only statistical software. In addition, this may be economically unreasonable in the long term.

The article only took into consideration one rescue team. Assuming that there are 40 such teams dispersed over the area of an administrative unit, the number of mathematical operations would be unimaginably large. Therefore, it would be recommended to develop a computer program able to do all these simulations and present them in a user-friendly graphical form.

It would be extremely helpful if the data for that program could be automatically downloaded from the decision support system of the emergency services, e.g.: from the SWD- ST 2.5 system. It would be even better if this new software became part of the decision support system used today. It seems that such a solution is a natural evolutionary step for decision support systems. However, this would require introducing certain changes, not only in the existing software, but also in the mentality of rescuers and dispatchers.

Designing such systems and changing the mentality of their users should improve the efficiency of the emergency services in the sense of better performance at lower costs. This includes primarily shorter rescue-team arrival times, and more effective help provided to the victims.

\section{Literature / Literatura}

[1] Johnson N. L., Kotz S., Balakrishnan N., No 14: Lognormal Distributions, in: Continuous univariate distributions. Vol. 1, Wiley Series in Probability and Mathematical Statistics: Applied Probability and Statistics (2nd ed.), John Wiley \& Sons, New York 1994.

[2] Kielin J., Wojtasiak B., Mazur J., Bąk D., Bujny P., Wstępny model ustalania wskaźnika gotowości operacyjnej JR - JRG i OSP, w: Projektowanie systemu ratowniczego, J. Zboina, J. Kielin (red.), Wyd. CNBOP-PIB, Józefów 2015.

[3] Prońko J., Kielin J., Wojtasiak B., Przestrzenna analiza zagrożeń na podstawie danych historycznych, BITP Vol. 39 Issue 3, 2015, 77-93, https://doi.org/10.12845/bitp.39.3.2015.7.
- $\quad$ wyznaczanie obszarów operacyjnej odpowiedzialności poszczególnych jednostek ratowniczych;

- wyznaczanie miejsc stacjonowania poszczególnych jednostek adekwatnie do przestrzennej gęstości zdarzeń wymagających działań ratowniczych

- ocenę gotowości operacyjnej poszczególnych zespołów i jednostek (grup zespołów);

- dopasowanie potencjału jednostek ratowniczych do ilości i rodzaju zdarzeń wymagających ich reakcji;

- ocenę dostępności zespołów ratowniczych - stanowi ona jeden z elementów określania ich potencjału;

- wspomaganie procesu decyzyjnego dysponentów służb ratowniczych.

Prowadzenie obliczeń (estymacja parametrów i dobór rozkładów teoretycznych) oraz symulacji pozwalających na rozwiązywanie powyższych problemów z wykorzystaniem jedynie oprogramowania statystycznego jest bardzo uciążliwe i w dłuższej perspektywie czasowej może być ekonomicznie nieuzasadnione. W artykule rozważano tylko jeden zespół ratowniczy. Przy założeniu, że takich zespołów na terenie jednostki administracyjnej jest 40, ilość operacji matematycznych urasta do wprost niewyobrażalnej liczby. Dlatego też wskazanym byłoby opracowanie programu komputerowego, który byłby zdolny do przeprowadzenia wszystkich symulacji i zaprezentowania ich w przyjaznej dla odbiorcy formie graficznej. Ogromnym ułatwieniem byłoby, gdyby dane do tego programu mogły być automatycznie pobierane z systemu wspomagania decyzji dysponenta służb ratowniczych, np.: z systemu SWD- ST 2,5. Jeszcze lepsze efekty przyniosłoby włączenie nowego oprogramowania do wykorzystywanego dziś systemu wspomagania decyzji. Wydaje się, że takie rozwiązanie jest normalną drogą ewolucji systemów wspomagania decyzji. Wymaga to jednak dokonania pewnych zmian nie tylko w obecnym oprogramowaniu, ale również w mentalności ratowników i dyspozytorów.

Budowa podobnych systemów i zmiana mentalności ich użytkowników ma służyć poprawie efektywności działania służb ratowniczych, rozumianej jako osiąganie większych efektów przy niższych nakładach ekonomicznych. Zalicza się tu przede wszystkich krótszy czas dotarcia ratowników na miejsce zdarzenia oraz skuteczniejsza pomoc poszkodowanym.

[4] Prońko J., Kielin J., Wojtasiak B., Klasyfikacja zdarzeń na podstawie danych historycznych, BITP Vol. 39 Issue 3, 2015, 93-111, https://doi. org/10.12845/bitp.39.3.2015.8.

[5] Trocki M., Grucza B., Ogonek K., Zarządzanie projektami, PWE, Warszawa 2003.

[6] Ustawa z dnia 8 września 2006 r. o Państwowym Ratownictwie Medycznym (Dz. U. 2006 Nr 191, poz. 1410 z późn. zm.).

[7] Wawrzynek J., Metody opisu i wnioskowania statystycznego, Wyd. AE im. Oskara Langego, Wrocław 2007.

[8] Wojtasiak B., Mazur J., Bąk D., Bujny P., Analiza czasu podejmowania Pierwszej Pomocy Ratowniczej przez zespoły ratownicze, w: Projektowanie systemu ratowniczego, J. Zboina, J. Kielin (red.), Wyd. CNBOP-PIB, Józefów 2015 
JAROSŁAW PRONKKO, D.SC. - Professor Extraordinarius at the Institute of Management of the Jan Kochanowski University in Kielce. He graduated from the Kielce University of Technology and the National Defence University of Warsaw. He is a former officer of the Vistula Military Units. He participated in the flood operations of 1997, for which he was awarded the Cross of Merit for Bravery. Between 1998 and 2001 he worked as Chief Expert at the Defence Affairs Office of the Ministry of Interior and Administration. He has authored and co-authored many publications on national defence, crisis management, and a number of subjects related to decision making and risk analysis in the field of public security.

SEN. BRIG. JACEK ZBOINA, PH.D. - Deputy Director for Certification and Acceptance at CNBOP-PIB. He graduated from the Main School of Fire Service, the Warsaw School of Economics and the Polish Naval Academy in Gdynia. He worked as Fire Risk Surveyor under the Chief Commandant of the State Fire Service. His research and professional interests include safety, fire protection, technical fire security systems, and compliance assessment. He is the author or co-author of several dozen scientific and specialist papers on safety, fire protection, technical security systems, product testing and certification, the practical use of new technologies, and the development of innovations.

He has been involved in the implementation and management of research and research \& development projects.

BEATA WOJTASIAK, M.A. - she graduated from the Maria Grzegorzewska University in Warsaw. In 2013 she completed a postMaster's programme in Innovation Management at the Warsaw School of Economics. Currently, she is working CNBOP-PIB Technical Assessment Department.

SEN. BRIG. (RETD.) JAN KIELIN, M.SC. ENG. - he graduated from the School of Fire Service Officers in Warsaw and the Higher School of Fire Service Officers in Warsaw. In 1975 he became a licensed fire risk surveyor. He has authored many publications and translations on fire protection.

MARTA IWAŃSKA, M.A. - she graduated from Collegium Civitas in Warsaw, Faculty of Social Sciences, majoring in Non-Governmental Organisation Management. She works as an engineering expert for standardisation at the Certification Department of CNBOP-PIB.
DR HAB. JAROSŁAW PROŃKO - profesor nadzwyczajny Instytutu Zarządzania Uniwersytetu Jana Kochanowskiego w Kielcach. Absolwent Politechniki Świętokrzyskiej i AON. Były oficer Nadwiślańskich Jednostek Wojskowych. Uczestnik akcji przeciwpowodziowej w 1997 r. - odznaczony Krzyżem Zasługi za Dzielność. W latach 1998-2001 główny specjalista w Biurze Spraw Obronnych MSWiA. Autor i współautor wielu prac z zakresu bezpieczeństwa powszechnego, zarządzania kryzysowego, problematyki podejmowania decyzji oraz analizy ryzyka w obszarze bezpieczeństwa powszechnego.

ST. BRYG. DR INŻ. JACEK ZBOINA - Z-ca Dyrektora ds. Certyfikacji i Dopuszczeń CNBOP-PIB. Absolwent Szkoły Głównej Służby Pożarniczej, Szkoły Głównej Handlowej w Warszawie oraz Akademii Marynarki Wojennej w Gdyni. Rzeczoznawca Komendanta Głównego PSP ds. zabezpieczeń przeciwpożarowych.

Jego zainteresowania badawcze oraz praca zawodowa obejmują: bezpieczeństwo, ochronę przeciwpożarową, techniczne systemy zabezpieczeń przeciwpożarowych oraz ocenę zgodności. Autor i współautor kilkudziesięciu publikacji naukowych oraz branżowych w zakresie bezpieczeństwa, ochrony przeciwpożarowej, technicznych systemów zabezpieczeń, badań, testowania i certyfikacji wyrobów, a także wykorzystania w praktyce nowych technologii i tworzenia innowacji. W działalności badawczej i zawodowej uczestniczy w pracach w projektach badawczych i badawczo-rozwojowych - zarówno w roli wykonawcy, jak i kierownika.

MGR BEATA WOJTASIAK - absolwentka Akademii Pedagogiki Specjalnej w Warszawie. W 2013 r. ukończyła studia podyplomowe Menedżer Innowacji w Szkole Głównej Handlowej w Warszawie. Obecnie pracuje w Zakładzie Ocen Technicznych CNBOP-PIB.

ST. BRYG. W ST. SP. MGR INŻ. JAN KIELIN - absolwent Szkoły Oficerów Pożarnictwa w Warszawie oraz Wyższej Oficerskiej Szkoły Pożarniczej w Warszawie. W roku 1975 uzyskał uprawnienia rzeczoznawcy do spraw zabezpieczeń ppoż. Autor wielu publikacji oraz tłumaczeń z zakresu ochrony przeciwpożarowej.

MGR MARTA IWAŃSKA - absolwentka Collegium Civitas w Warszawie na Wydziale Socjologii, kierunek zarządzanie organizacjami pozarządowymi. Specjalista inżynieryno-techniczny ds. normalizacji Jednostki Certyfikującej CNBOP-PIB. 